\title{
Climate Change Effects on Aquaculture Production: Sustainability Implications, Mitigation, and Adaptations
}

\begin{abstract}
Sahya Maulu ${ }^{1,2 *}$, Oliver J. Hasimuna ${ }^{3,4}$, Lloyd H. Haambiya ${ }^{5}$, Concillia Monde ${ }^{6}$, Confred G. Musuka ${ }^{6}$, Timothy H. Makorwa ${ }^{2,7}$, Brian P. Munganga ${ }^{1,2}$, Kanyembo J. Phiri ${ }^{1}$ and Jean DaMascene Nsekanabo ${ }^{2,8}$

${ }^{1}$ Centre for Innovative Approach Zambia, Lusaka, Zambia, ${ }^{2}$ Wuxi Fisheries College, Nanjing Agricultural University, Wuxi, China, ${ }^{3}$ Department of Fisheries, National Aquaculture Research and Development Centre, Ministry of Fisheries and Livestock, Kitwe, Zambia, ${ }^{4}$ Department of Zoology and Aquatic Sciences, School of Natural Resources, Copperbelt University, Kitwe, Zambia, ${ }^{5}$ Lake Tanganyika Fisheries Research Unit, Ministry of Fisheries and Livestock, Mpulungu, Zambia, ${ }^{6}$ Department of Agriculture and Aquatic Sciences, Kapasa Makasa University, Chinsali, Zambia, ${ }^{7}$ Morogoro Fisheries Center, Ministry of Fisheries and Agriculture, Morogoro, Tanzania, ${ }^{8}$ College of Science and Technology, University of Rwanda, Kigali, Rwanda
\end{abstract}

OPEN ACCESS

Edited by:

Sanzidur Rahman,

Shandong University of Finance and

Economics, China

Reviewed by:

Nesar Ahmed,

Deakin University, Australia

Alexander Godfrey Murray,

Marine Scotland, United Kingdom

*Correspondence:

Sahya Maulu

sahyamaulu@gmail.com

Specialty section

This article was submitted to Climate-Smart Food Systems,

a section of the journal

Frontiers in Sustainable Food Systems

Received: 22 September 2020

Accepted: 18 February 2021

Published: 12 March 2021

Citation:

Maulu S, Hasimuna OJ Haambiya LH, Monde C, Musuka CG, Makorwa TH, Munganga BP, Phiri KJ and Nsekanabo JD (2021) Climate

Change Effects on Aquaculture Production: Sustainability Implications, Mitigation, and Adaptations.

Front. Sustain. Food Syst. 5:609097. doi: 10.3389/fsufs. 2021.609097
Aquaculture continues to significantly expand its production, making it the fastest-growing food production sector globally. However, the sustainability of the sector is at stake due to the predicted effects of climate change that are not only a future but also a present reality. In this paper, we review the potential effects of climate change on aquaculture production and its implications on the sector's sustainability. Various elements of a changing climate, such as rising temperatures, sea-level rise, diseases and harmful algal blooms, changes in rainfall patterns, the uncertainty of external inputs supplies, changes in sea surface salinity, and severe climatic events have been discussed. Furthermore, several adaptation options have been presented as well as some gaps in existing knowledge that require further investigations. Overall, climate change effects and implications on aquaculture production sustainability are expected to be both negative and positive although, the negative effects outweigh the positive ones. Adapting to the predicted changes in the short-term while taking mitigation measures in the long-term could be the only way toward sustaining the sector's production. However, successful adaptation will depend on the adaptive capacity of the producers in different regions of the world.

Keywords: adaptation, aquaculture production, climate change, greenhouse gases, effects, sustainability

\section{INTRODUCTION}

The practice of aquaculture is a way to achieve sustainability in the production of aquatic products. With the continued unsustainable harvests from capture fisheries, the sector is seen as the only solution to meeting the rising demand for aquatic products globally (AskarySary et al., 2012; FAO, 2020). According to FAO (2020), aquaculture's contribution to global fish production has continued to rise, reaching 82.1 million tons (46\%) out of the estimated 179 million tons of global production. Furthermore, the share of aquaculture production out of the global fish production is expected 
to grow from the current 46 to $53 \%$ in 2030 (FAO, 2020). However, the most urgent concern is whether the sector is growing sustainably and fast enough to meet the future projected demand exacerbated by a rapidly growing human population and a changing climate. Climate change is now considered a risk to global food production and a major threat to the quality and quantity of production (Beach and Viator, 2008; Hamdan et al., 2015; Myers et al., 2017). Food security, particularly access to dietary protein, is increasingly being threatened by the predicted effects of climate change (Kandu, 2017).

Climate change refers to variations that occur in the statistical distribution of weather over extended periods, typically ranging from decades to millions of years (Yazdi and Shakouri, 2010; IPCC, 2014). These variations may occur in the average weather or simply in the distribution of weather events around an average, and may be limited to a particular region, or occurring across the whole globe (Yazdi and Shakouri, 2010). Humans have been recognized as the major contributor to climate change through the use of fossil fuels (coal, oil, and gas) for energy supplies (Doubleday et al., 2013; Environmental Protection Agency, 2016; Gao et al., 2016; Barange et al., 2018; IPCC, 2019, Palmer and Stevens, 2019) as well as deforestation and forest degradation (Khaine and Woo, 2015; Riphah, 2015) that emit greenhouse gases (GHGs) into the atmosphere. The increased accumulation of GHGs including Carbon dioxide $\left(\mathrm{CO}_{2}\right)$, methane $\left(\mathrm{CH}_{4}\right)$, nitrous oxides $\left(\mathrm{N}_{2} \mathrm{O}\right)$, and fluorinated gases in the atmosphere over the years has been linked to these human activities. Already, climate change effects have been reported on various key economic sectors and services globally (Troell et al., 2017; IPCC, 2018; Cook and Zolnikov, 2019; FAO, 2020). In aquaculture, the majority of recent literature indicate that some changes in climate, such as rising temperatures, changing precipitation patterns, and increased frequency of some extreme events are now evident on water resources, while others are still emerging (Fleming et al., 2014; Blanchard et al., 2017; Troell et al., 2017; Zolnikov, 2019). Recently, climate change effects on aquaculture sustainability have gained considerable interest owing to the sector's significant contribution to global food security, nutrition, and livelihoods (Blanchard et al., 2017; Dabbadie et al., 2018; FAO, 2020). Despite some aspects of uncertainty, several projections show that the entire aquaculture value chain is vulnerable to the effects of climate change (Cochrane et al., 2009; Fleming et al., 2014; Bueno and Soto, 2017; Barange et al., 2018; Dabbadie et al., 2018). However, the majority of the available literature is largely biased toward showing how climate change will affect aquaculture production systems leaving, other stages in the value chain unclear (Fleming et al., 2014). Such biases limit our current understanding of the various extents to which the aquaculture sector will be affected. Additionally, the absence of global models that can take into account both the direct and indirect effects of climate change on aquaculture makes the quantification of the effects difficult (Metian, 2017). What is certain, however, is that the effects will be persistent and likely to be irreversible, resulting in severe consequences on the economy of those engaged in the sector, with extreme effects projected on poorer communities (IPCC,
2013, 2014; Holmyard, 2014; Barange et al., 2018; Dabbadie et al., 2018).

The effects of climate change on aquaculture have been extensively studied and reviewed both at regional and global scales (De Silva and Soto, 2009; Yazdi and Shakouri, 2010; Clements and Chopin, 2016; Bueno and Soto, 2017; Chung et al., 2017; Ellis et al., 2017; Froehlich et al., 2017; Handisyde et al., 2017; Harvey et al., 2017; Klinger et al., 2017; Beveridge et al., 2018; Dabbadie et al., 2018). In the majority of these studies, however, there has been a tendency toward exploring the negative effects of climate change projected on aquaculture while giving far less attention to the positive ones that are very critical for adaptation strategies. A broader study of both the negative and positive sides of climate change will promote producers' preparedness and help minimize the risks on their production. Furthermore, the currently available literature reviews do not investigate how the sustainability of the aquaculture sector could be affected by the projected change in the climate. Such information is very useful for identifying appropriate interventions to climate change aiming to sustain livelihood sources for aquaculture-dependent communities. In this review, we have explored the negative and positive sides of climate change in relation to aquaculture production, and their implications for the sector's sustainability. The first section of the paper discusses the effects of climate change on aquaculture production and sustainability implications, by highlighting how each specific element of climate change will affect the sector. The section that follows presents some mitigation and adaptation options that may have a wider application as well as challenges to successful adaption. The last section concludes the findings and suggests the prospects for future development. To achieve this, a review of the recently published literature related to "Climate change and aquaculture" obtained from scientific, reputable, and internationally recognized journals and websites was conducted. It was beyond the aim of this paper to provide a comprehensive review of all published literature for each section covered, rather, it focuses on the most recent (not more than 10 years back) and relevant literature on the subject. However, the priority in the selection of reviewed papers was given to the most recently published literature with a global and/or regional context with few exceptions.

\section{THE EFFECTS OF CLIMATE CHANGE ON AQUACULTURE AND IMPLICATIONS ON SUSTAINABILITY}

Climate change effects on aquaculture production are expected to be both direct and indirect (Handisyde et al., 2006; De Silva and Soto, 2009). The direct effects include influencing the physical and physiology of finfish and shellfish stocks in production systems, while indirect effects may occur through altering the primary and secondary productivity, and structure of the ecosystems, input supplies or by affecting product prices, fishmeal, and fish oil costs, and other goods and services needed by fishers and aquaculture producers (Handisyde et al., 2006; De Silva and Soto, 2009; Freeman, 2017; Adhikari et al., 2018). 
The various ways through which climate change will affect aquaculture production and implications on the sustainability of the sector are presented in detail later in this section. There is a consensus that aquaculture production does not occur in a vacuum, it has important links with other food production systems (De Silva and Soto, 2009; Troell et al., 2014). Moreover, Blanchard et al. (2017), observed that to sustainably meet the ever-increasing demand for aquatic products, there is a need to recognize the strong link existing within and across the goals of fisheries, aquaculture, and agriculture systems. Figure 1 provides a simple illustration of how GHG emissions will affect aquaculture production as well as the contribution of capture fisheries, aquaculture, and agriculture activities to climate change.

Although aquaculture activities, such as power input, transport, and feed production are considered the main pathways of the sector's contribution to GHGs (Cochrane et al., 2009; Adhikari et al., 2018; Barange et al., 2018), the sector's contribution is rather relatively small despite being significant when compared to other food production sectors (Barange et al., 2018). For example, the contribution of aquaculture to global GHGs particularly $\mathrm{CO}_{2}$, emission in 2010 was estimated at 385 million tons, $\sim 7 \%$ of the agricultural sector's contribution that year (Barange et al., 2018). Recent estimates by IPCC (2019) show that agriculture, forestry, and other land uses contributed about $13 \% \mathrm{CO}_{2}, 44 \% \mathrm{CH}_{4}$, and $82 \% \mathrm{~N}_{2} \mathrm{O}$ emissions from anthropogenic activities for the period 2007-2016, accounting for $23 \%$ of net anthropogenic emissions of GHGs. It is estimated that $45 \%$ of the total net contribution by agriculture comes from animal production, particularly livestock farming (Preto et al.,
2015), which contributes mainly $\mathrm{CH}_{4}, \mathrm{CO}_{2}$, and $\mathrm{N}_{2} \mathrm{O}$, making it the sector's largest contributor (De Silva and Soto, 2009; Preto et al., 2015; Zolnikov, 2018). On the other hand, aquaculture's main GHGs emission is $\mathrm{CO}_{2}$ through the normal respiration of aquatic animals (De Silva and Soto, 2009). However, there is still a gap in existing knowledge regarding the pathways and contribution of aquaculture production to global GHGs emission, which requires further investigations. The contribution of fisheries, mainly $\mathrm{CO}_{2}$ to the net food production GHGs emission contribution was estimated at $4 \%$ in 2011, while the percent increase of emissions from the global fisheries industry was estimated at 28\% between 1990 and 2011 mainly due to increased fishing operations (Daw et al., 2009; Parker et al., 2018).

Recently, aquaculture has recorded significant technological advances that enable the sector to expand its current production toward meeting the rising demand for aquatic products (Kobayashi et al., 2015; Morris et al., 2019; FAO, 2020). However, climate change is increasingly becoming one of the major issues confronting the sustainability of food production systems and aquaculture is no exception (Lim-Camacho et al., 2014; IPCC, 2018; FAO, 2020). According to IPCC (2018), sustainable development which balances environmental protection, economic prosperity, and social well-being is closely linked to climate change effects and responses. This suggests that it is impossible to achieve sustainability in aquaculture production without addressing climate change effects. Sustainability, despite many definitions available (Johnston et al., 2007), can refer to the management of financial, technological, institutional, natural, and social resources to ensure a constant supply of human needs, not only for the present but also for the future

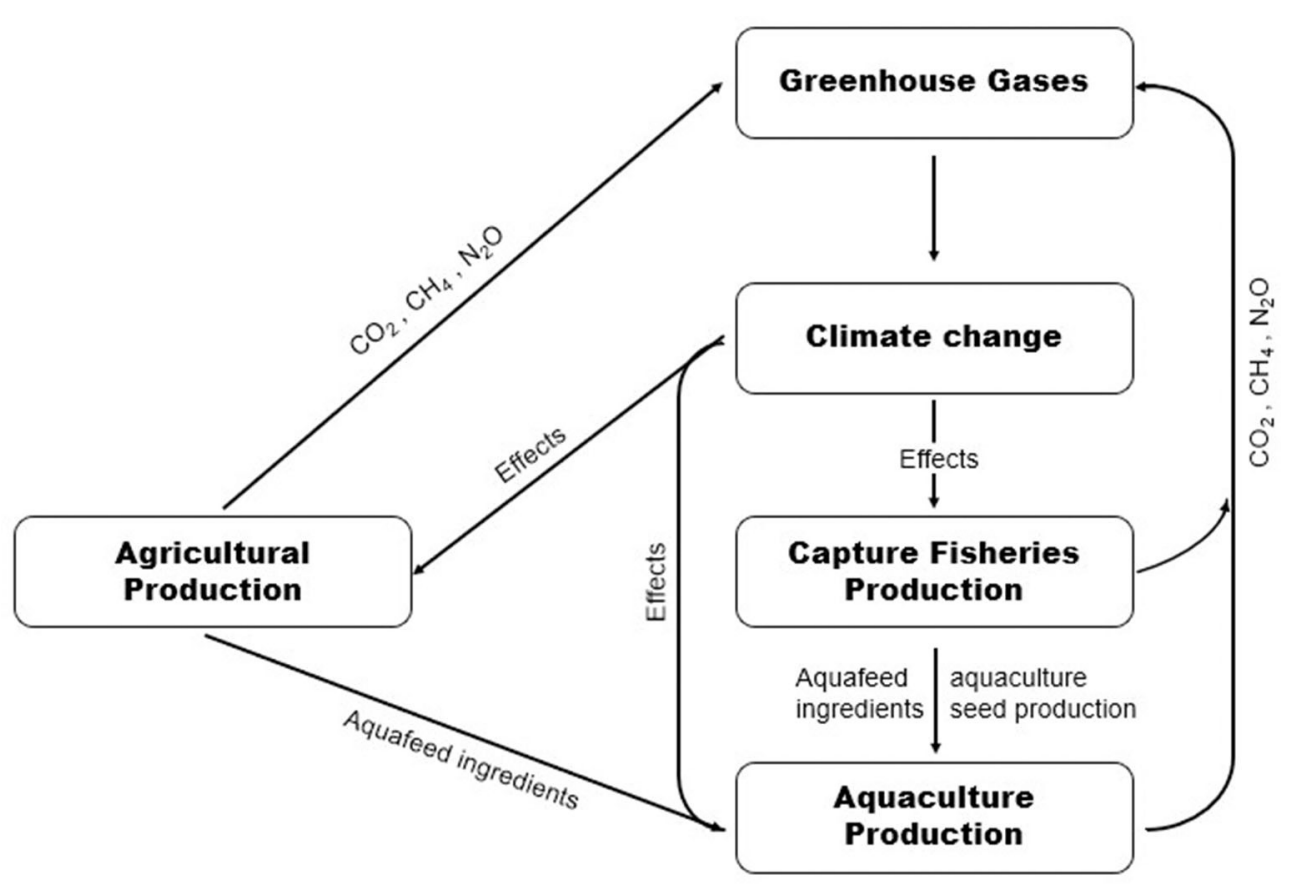

FIGURE 1 | A simple illustration of the direct and indirect pathways through which climate change will affect aquaculture production. 
generations (Valenti et al., 2018). Therefore, for aquaculture to be sustainable, it must survive throughout generations (Valenti et al., 2011). According to Valenti et al. (2018), the sustainability of aquaculture systems may be assessed using three sustainability indicators: environmental, economic, and social indicators. Environmental sustainability indicators include the efficient utilization of natural resources, pollution prevention, and biodiversity conservation (Valenti et al., 2018). Economic sustainability focuses on the efficient use of financial resources, economic feasibility, resilience and the capacity to absorb negative external expenses, and generation of funds for re-investment; while social sustainability focuses on the capacity of aquaculture to provide benefits to communities, such as food security, employment, equality of income and opportunity distribution, and inclusion of vulnerable population (Valenti et al., 2011, 2018). However, the currently available literature on aquaculture sustainability has largely focused on environmental sustainability, with far less attention being given to the other two equally important dimensions (Tisdell and Leung, 1999; Ahmed et al., 2019; Engle, 2019). Future studies should critically investigate how climate-induced changes may affect the social and economic aspects of aquaculture production sustainability. A case study conducted in Ghana showed that climate-related changes could significantly lower the economic value of aquaculture products and induce poverty especially in rural communities (Asiedu et al., 2019). Much of what is currently available in the literature are predictions based on scientific models.

Numerous reports have emerged showing that climate change effects on aquaculture may vary depending on geographical areas, economy, climatic zones, production systems, and cultured species (Merino et al., 2012; Bell et al., 2013; Cheung et al., 2013; Sae-Lim et al., 2017; Adhikari et al., 2018; Barange et al., 2018; IPCC, 2018; Zolnikov, 2019). For example, Barange et al. (2018) predicted higher effects on producers in developing nations and poorer economies compared with those in developed ones. Handisyde et al. (2017) reported that climate change effects on aquaculture producers are expected to differ depending on the culture environments (freshwater, brackish, and marine). Several other studies have also shown that small-scale farmers will be more affected by climate change risks due to increased production costs in farm management and lack of support systems to recover from the effects compared to large-scale producers (Schjolden, 2004; Sult et al., 2005; Hamdan et al., 2012; King and Harrington, 2018). Furthermore, it is important to note that climate change effects will not only affect aquaculture production systems, but also the entire value chain (Fleming et al., 2014; Barange et al., 2018). Hence, climate change could be more viewed as an involuntary risk that creates vulnerability on the socio-economic development and raises stress especially on food demand and supply as well as the livelihood system of the farmers.

The predicted elements of a changing climate that threatens production and sustainability of the aquaculture sector are summarized in Table 1, and include rising temperature, ocean acidification, diseases and harmful algal blooms changes in rainfall/precipitation patterns, sea-level rise, the uncertainty of external input supplies, changes in sea surface salinity, and severe climatic events (Handisyde et al., 2006; Brander, 2007; Ficke et al., 2007; Barange et al., 2018). These elements will not affect aquaculture production equally, since, like any other farming practice, the sector is defined in time, space, and size, and therefore, have a fair degree of maneuverability (De Silva and Soto, 2009) while affecting fish populations at different life cycles as well. Moreover, the current scientific knowledge regarding the effect of individual consequences varies and is often limited to the combined effects which make adaptation planning within the aquaculture sector practically difficult (Seggel et al., 2016).

\section{Rising Temperature}

Temperature plays a critical role in the growth and development of aquatic animals (Ngoan, 2018). Fish, being poikilothermic, may particularly be sensitive to temperature variations resulting from climate change (Sae-Lim et al., 2017; Adhikari et al., 2018). With the predicted $1.5^{\circ} \mathrm{C}$ rise in average global temperature this century, increased mortalities are likely to occur for most fish, especially cold-water species, such as the Atlantic halibut, Salmon and Cod, and intertidal shellfish due to thermal stress (Hamdan et al., 2012; Gubbins et al., 2013). Therefore, prolonged temperature stress may affect aquaculture productivity through various ways centered on lowered output. For example, chronic stress may affect the neuroendocrine and osmoregulatory systems, altering cardiorespiratory performance and aerobic scope as well as immune responses of several economically important species (Brodie et al., 2014; Gazeau et al., 2014; Paukert et al., 2016; Stévant et al., 2017; Stewart et al., 2019; Zhang et al., 2019). Furthermore, metabolism and physiology, as well as feeding behavior and growth performance of most finfish and shellfish species are likely to be affected (Marcogliese, 2008; Akegbejo-Samsons, 2009; Lemasson et al., 2018). Additionally, rising ocean temperatures and consequential ocean acidification slowly weaken the ocean carbon sink capacity, giving rise to alterations in the hydrology and hydrography of water systems, and the occurrence of red tides (Cochrane et al., 2009). These effects may lead to increased management costs and low productivity that threaten the economic and social sustainability of aquaculture production. Environmental sustainability may also be affected by thermal stratification in deep water bodies resulting from temperature variations which may affect the distribution and abundance of nutrients in the water, and in case of upwelling occurrence, aquaculture producers operating in open waters will suffer from severe economic losses (Seggel et al., 2016). However, information regarding the physiological response of the most economically important species to rising temperature is still limited to few species, and biased toward adult stages, leaving initial ontogenetic stages, such as embryos, larvae, and fingerlings unclear.

On the other hand, warmer periods (within species' tolerance conditions) may promote longer growing seasons, especially in temperate regions, and favor the production of warmer water species, such as the Giant tiger prawn, Tilapia, Oysters, and Mussels (Pickering et al., 2011; Troell et al., 2017; Guyondet et al., 2018; Collins et al., 2020). Larger-scale investors that run hatcheries in sheltered locations may also benefit from 
TABLE 1 | Summary of the various elements of climate change and their effects on aquaculture production.

Effects

Negative effects

$\begin{array}{ll}\text { - Poor growth and } & \text { - Reduced species } \\ \text { survival of cold-water } & \text { growth performance } \\ \text { species (Hamdan } & \text { and survival } \\ \text { et al., 2012; Gubbins } & \text { (Clements and } \\ \text { et al., 2013) } & \text { Chopin, 2016; IPCC, - } \\ \text { - Water quality } & \text { 2018) } \\ \text { deterioration (Ngoan, } & \text { - Poor coral skeleton } \\ \text { 2018) } & \text { development for } \\ \text { - Weakened immune } & \text { shell-forming species } \\ \text { system of cold-water } & \text { (Hoegh-Guldberg } \\ \text { species (Gubbins } & \text { et al., 2007; } \\ \text { et al., 2013) } & \text { Weatherdon et al., } \\ \text { - Weakened ocean } & \text { 2016; Kibria et al., } \\ \text { carbon sink capacity } & \text { 2017) } \\ \text { (Cochrane et al., } & - \text { Increased water } \\ \text { 2009) } & \text { acidity levels } \\ \text { - Thermal stratification } & \text { (Rodrigues et al., } \\ \text { (Seggel et al., 2016) } & \text { 2015; Clements and } \\ \text { - Increased virulence } & \text { Chopin, 2016) } \\ \text { of warmer water } & - \text { Increased production } \\ \text { pathogens (Sae-Lim } & \text { costs in marine areas } \\ \text { et al., 2017) } & \text { (Munday et al., 2011; } \\ & \text { Frommel et al., 2012) }\end{array}$

Positive effects

Extended growing seasons for warmer water species

(Pickering et al.,

2011; Gubbins et al.,

2013: Troell et al.,

2017; Guyondet

et al., 2018)

- Further

developments in

genetic breeding

possibility (Gubbins

et al., 2013;

Blanchard et al.,

2017)

feasibility in et al., 2013)

culture (Gubbins
Diseases and Changes in

harmful algal blooms rainfall/precipitation

patterns

Poor species growth -

wth - Droughts could

increase production

costs (Hambal et al.

(Marcogliese, 2008;

Sae-Lim et al., 2017) 1994

Competing use of

quality (Ngoan, 2018) water during periods

of drought

costs due to disease (Handisyde et al.

outbreaks (Gubbins

et al., 2013).

2006; Cochrane

et al., 2009)

- Flooding may

increase loss of

of exotic diseases

(Gubbins et al.,

2013).

organisms in low

areas (Bell et al.,

2010; Rutkayova

et al., 2017)

Flooding could

deteriorate water

quality and pollute

the environment

(Kibria et al., 2017)

Destruction of

production facilities

(Bell et al., 2010;

Rutkayova et al.

2017)

- Increased production - Possible elimination

of cold-water

Flooding may

increase suitable

- May increase areas suitable for brackish pathogens (Sae-Lim et al., 2017)

quaculture

production in some

(a)

- May facilitate the

development of

regions (Bell et al.

2013)

species with better

Droughts could

promote

shrimps and mud

crab (Handisyde

et al., 2006; Kibria

(Sae-Lim et al., 2017) developments in

et al., 2017)

wastewater

and development of management

new species (Beveridge et al.

(Blanchard et al., 2018)

2017)
External input

Sea surface salinity Climatic events

supplies uncertainty

\section{Increased costs of}

production due to

possible increase in

the costs of inputs,

such as fish feeds

and seed (Hardy,

2010; Blanchard

et al., 2017; Bueno

and Soto, 2017;

Khatri-Chhetri et al.,

2019)

- Reduced ocean's - Destruction of

heat storage capacity production systems

(Seggel et al., 2016) (Hamdan et al., 2012)

Reduced carbon and - Increased

nutrients circulation management costs

(Seggel et al., 2016) (Canadian Institute

- Increased species for Climate Studies,

mortalities (Jahan 2000)

et al., 2019) - Increased loss of

culture species

(Hamdan et al., 2012)

Possible identification -

of alternative and

Possible increase in sustainable input

the cultivation of

Better mixing of water

supplies, such as

tolerant species

replace conventional

sources (Hardy,

2010) 
market opportunities emerging due to the decline of preferred specimens in the wild as a result of degrading coral reefs (Bell et al., 2010). In cold regions, such as the Arctic, warmer periods are projected to favor the expansion of aquaculture production (Chan et al., 2019). Besides, warmer periods may provide opportunities to culture new species and facilitate further developments in genetic improvements of aquatic organisms (Gubbins et al., 2013; Bueno and Soto, 2017). These opportunities will favor social sustainability through increased production outputs and employment opportunities, and economic sustainability through increased profits and reduced management costs in these areas. However, achieving this will require advances in molecular biology and applying practical methods of genetic improvement in aquaculture although this may threaten environmental sustainability in case of hybridization with species in natural waters.

\section{Ocean Acidification}

Ocean acidification occurs due to a decline in $\mathrm{pH}$ levels of ocean water for an extended period (usually over decades) resulting from atmospheric $\mathrm{CO}_{2}$ uptake (Richards et al., 2015; Bahri et al., 2018). The oceans are estimated to store about 50 times more $\mathrm{CO}_{2}$ than the atmosphere (Seggel et al., 2016). The projected increase in $\mathrm{CO}_{2}$ uptake by oceans at $1.5^{\circ} \mathrm{C}$ or more global warming will have adverse effects on the growth, development, calcification, survival, and abundance of several aquatic species (IPCC, 2018). Increased accumulation of $\mathrm{CO}_{2}$ in water could result in increased water acidity levels $(\mathrm{pH}$ decrease) (Rodrigues et al., 2015; Clements and Chopin, 2016) which threatens the environmental sustainability of aquaculture production systems through water quality deterioration leading to poor productivity. Moreover, the rise in ocean acidity reduces the availability of carbonate required for the construction of coral skeletons (Calcification) in shell-forming organisms, such as shrimps, mussels, oysters, or corals (Hoegh-Guldberg et al., 2007; Weatherdon et al., 2016; Kibria et al., 2017), which potentially threatens marine aquaculture production (Yazdi and Shakouri, 2010; Kroeker et al., 2014; Rodrigues et al., 2015). For example, wild spat oyster production may decline due to increased predation rates of the juveniles following poor coral skeleton formation which lowers the collection rates (Blanchard et al., 2017). Consequently, this is likely to force large-scale producers to rely on hatcheries for spat oyster production which increases the production costs. This could lower production outputs and profits, and pose negative implications on the social and economic sustainability of aquaculture production in these regions. In seawater, rising acidity levels could significantly affect the physiology and metabolism of aquatic species by disrupting the intercellular transport mechanisms (Pörtner et al., 2004). Although difficult to capture at a global scale (Froehlich et al., 2018), the ability of species to respond to changes in ocean acidity will depend on species adaptive capacity (Thomsen et al., 2017), rate of change (Cooley et al., 2012; Mangan et al., 2017), as well as complex biophysical feedbacks (Silbiger and Sorte, 2018). Macroalgal (seaweed) production may also be affected by ocean acidification, but such effects will depend on the acquisition kinetics of inorganic carbon by different species (Chung et al.,
2017). For example, calcifying species in locations where $\mathrm{CO}_{2}$ is not the major driver of acidification are predicted to be the most affected (Cornwall et al., 2012; Clements and Chopin, 2016). Although seaweed is considered an important sink for atmospheric $\mathrm{CO}_{2}$ (Chung et al., 2013, 2017; Duarte et al., 2017), few studies have evaluated the effects of climate change on seaweed production, probably because its production is limited to certain regions (Sondak et al., 2016). According to Gubbins et al. (2013), however, the future changes in ocean carbonate chemistry are difficult to predict with any certainty and the effects of this are hard to expound because of the difficulties associated with monitoring long-term biological responses to very small changes observed under experimental conditions. Furthermore, the majority of the available reports from experiments regarding the effects of ocean acidification on aquaculture species have been conducted in combination with rising temperature effects (Rodrigues et al., 2015).

A positive impact of ocean acidification is that the partial or total dependence of large-scale aquaculture producers on hatcheries for spat production may create huge economic gains for the hatchery owners. Additionally, this may provide more employment opportunities to local communities since these hatcheries will require huge labor in response to the growing demand, thereby favoring the social and economic sustainability of aquaculture production. Although the effects of ocean acidification on finfish is poorly understood (Wittmann and Pörtner, 2013; Clements and Chopin, 2016), the presence of calcified otoliths in finfish, especially marine species, makes them susceptible to ocean acidification (Clements and Chopin, 2016), and their growth and development may particularly be affected (Frommel et al., 2014), RNA viability (Franke and Clemmesen, 2011), and damage tissues, and impairing respiration (Munday et al., 2009; Frommel et al., 2012).

\section{Diseases and Harmful Algal Blooms}

Diseases in aquaculture, such as bacterial, parasitic, viral, and fungal diseases are likely to be affected by a changing temperature regime, but in a largely unpredictable manner (Collins et al., 2020). What is certain, however, is that when cultured species are exposed to thermal stress conditions, they become more susceptible to diseases and that warmer conditions may result in the establishment of exotic diseases (Collins et al., 2020). The vulnerability of finfish and shellfish to pathogens is a major determinant of diseases and is likely to be affected by both direct and indirect thermal stressors (Chiaramonte et al., 2016). Therefore, warm water disease outbreaks are predicted to occur more frequently in addition to the possibility of discovering new ones under a changing climate (Sae-Lim et al., 2017). Rising temperature is likely to accelerate the replication rate, virulence, life cycle longevity, and transmission of pathogens among several finfish and shellfish species (Marcogliese, 2008). Moreover, the increasing temperature pressures may promote the emergence of epizootic diseases in aquaculture and cause serious economic challenges. Already, the outbreak of epizootic diseases remains one of the most important factors that limit the success of aquaculture production systems in many countries of the world (Maulu et al., 2019). It is also predicted that 
warm water pathogens, such as Sea lice will remain a challenge in salmon culture and further warming is likely to worsen the infections in cold temperate conditions, requiring more treatments thus more expenses (Collins et al., 2020). Overall, the increased occurrence of diseases in aquaculture production systems will lead to reduced profits, consequently, affecting the social and economic sustainability aspects of aquaculture production. Conversely, cold water diseases, such as vibriosis and winter ulcer that affects Atlantic salmon may gradually become extinct due to the emerging unfavorable conditions (Sae-Lim et al., 2017) which may favor the production of this fish species.

Several studies have also associated the outbreak of some harmful algal blooms to the changes in climatic conditions (Wasmund et al., 1998; Edwards and Richardson, 2004; Edwards et al., 2006; Moore et al., 2008; De Silva and Soto, 2009; Lafferty, 2009; Trainer et al., 2019). Algal blooms are a serious threat to the environmental sustainability of aquaculture production. For example, flagellates and dinoflagellates taxonomic groups, and other harmful species have been reported to contain potentially toxic or nuisance species that can be responsible for stress or kills in finfish and shellfish (Hinder et al., 2012; Gubbins et al., 2013; Basti et al., 2019). Consequently, this could have negative implications on the social and economic aspects of aquaculture sustainability. Recently, an unprecedented loss of fish ever recorded worldwide was reported in Chilean aquaculture due to the expansion of Pseudochattonella $c f$. verruculosa and Alexandrium catenella species whose outbreak were associated with climate-induced changes in water column stratification (Trainer et al., 2019). Furthermore, some studies have reported pathologies, such as inflammation, atrophy, and necrosis in several organs of bivalve mollusks resulting from harmful algal blooms (Haberkorn et al., 2010; Basti et al., 2011; Hégaret et al., 2012). Although there is limited information on the mechanisms through which climate change will affect toxic substances in aquaculture, Farrell et al. (2015) reported that temperature variation can affect the metabolism of most widespread harmful algae.

\section{Changes in Rainfall (Precipitation) Pattern}

Changes in rainfall patterns will affect aquaculture production and sustainability in two directly opposite ways; increased rainfall (Flooding) and periods of low or no rainfall (Drought). According to the IPCC (2018), risks resulting from droughts events are likely to be higher at $2^{\circ} \mathrm{C}$ compared with $1.5^{\circ} \mathrm{C}$ of global warming in a given region, while flooding event patterns are difficult to predict with certainty. Increased levels of rainfall, particularly if it occurs as heavier events, will increase the production risks in lowland areas (Bell et al., 2010). These risks include losing fish from ponds during floods, invasion of ponds by unwanted species, and ponds damage resulting from infilling and washing away of walls (Rutkayova et al., 2017). The mixing of pond water and fish with those in the wild could negatively affect the environmental sustainability of aquaculture production mainly through the introduction of invasive fish species and water quality deterioration. Furthermore, fish losses from ponds threaten the social and economic dimensions of aquaculture sustainability by lowering the economic gains of the producers and inducing poverty in communities. According to Rutkayova et al. (2017), however, the percent loss of fish during periods of extreme flooding will depend on the species and age of individual species. The authors further observed that percent losses are likely to decrease with increasing fish age. However, it should be noted that heavier rainfall may increase the areas suitable for aquaculture ponds that rely on rainwater in low-lying tropical regions, thereby favoring the social and economic sustainability in such regions (Bell et al., 2013). It is also reported that macroalgal, such as kelp productivity may be affected by heavier rainfall which may bring varied nutrient loadings to nearshore environments (Collins et al., 2020). Variability in nutrient loading under variable precipitation may also favor invasive short-lived algal species rather than the longer-lived kelp species normally considered suitable for cultivation (Gubbins et al., 2013).

Drought events may lead to water stress, such as shortages and quality deterioration that have negative effects on aquaculture production (Hambal et al., 1994). The predicted water shortages driven by climate change will lead to increased conflicts for water among the different user groups, such as aquaculture, agriculture, domestic, and industries (Handisyde et al., 2006; Barange et al., 2018). This will affect all the dimensions of aquaculture sustainability. However, there is a need to further investigate how different species and life stages of fish, especially those of economic importance will respond to changes in the precipitation pattern.

\section{Sea Level Rise}

Sea level rise projections by IPCC (2018) indicate that the rise will be around 0.1 meters lower under $1.5^{\circ} \mathrm{C}$ global warmings compared with $2^{\circ} \mathrm{C}$ by 2100 . However, this rise is expected to continue beyond 2100 with the magnitude and rate of the rise likely to depend on the future GHGs pathways (IPCC, 2018). The rise in sea level may destroy several coastal ecosystems, such as mangroves and salt marshes, which are considered crucial for maintaining wild fish stocks, as well as supplying seed for aquaculture production (Kibria et al., 2017). This will negatively affect aquaculture breeding programs and the economic sustainability of the sector. Higher sea level is predicted to affect aquaculture production facilities, such as ponds, cages, tanks, and pens particularly in lowland regions through the intrusion of saline water (Kibria et al., 2017). Salinization of groundwater is regarded as harmful to aquaculture, freshwater fisheries, and agricultural production (Handisyde et al., 2006; Kibria et al., 2017). Therefore, salinization renders aquaculture environmentally unsuitable for production leading to higher production costs and lower economic gains. Sea level rise is also likely to result in changes in species composition, organisms' abundance and distribution, ecosystem productivity, and phenological shifts that may threaten inland and marine aquaculture production (Doney et al., 2012). Besides, aquaculture activities in coastal areas bring social and environmental benefits that may be affected both directly and indirectly by rising sea levels thereby affecting the production and sustainability of the sector. On the positive side, sea-level rise may increase the areas suitable for brackish water culture of high-value species, such as shrimp and mud crab (Handisyde et al., 2006; Kibria 
et al., 2017). This may favor aquaculture production sustainability by presenting new opportunities for aquaculture production particularly those in coastal areas.

\section{Uncertainty of External Input Supplies}

Agriculture and capture fisheries are the primary sources of external inputs for aquaculture production, suggesting a strong relationship among these systems. According to Cochrane et al. (2009), aquaculture is a complementary activity to capture fisheries, and though more similar to agriculture in its practice, it has important links with capture fisheries. While agriculture is the main source of ingredients for energy requirements in aquatic animal feeds and likely to be the main supplier of protein sources in the future, capture fisheries are currently the principal supplier of protein sources as well as wild seed and broodstock for aquaculture (Hardy, 2010). Recently, due to the declining fish catches from capture fisheries, there has been an increasing channeling of cereal and soy production to aquaculture production for feed manufacturing (Ytrestoyl et al., 2015). However, due to its sensitivity to climate change effects, agricultural production is under threat and hence, the supply of these inputs to sustain aquaculture production continues to be threatened as well (Khatri-Chhetri et al., 2019). The impact of climate change on capture fisheries through alterations in the abundance and distribution of fish species will have a significant effect on fishmeal and fish oil supplies, and the sustainability of fish breeding programs due to increased scarcity of wild seeds (Bradley et al., 2015; Blanchard et al., 2017; Bueno and Soto, 2017). The ineffective management of fisheries and rising fishmeal prices are already a significant threat to aquaculture production sustainability (Black and Hughes, 2017). Moreover, the projected impacts of climate change on fishery resources are likely to accelerate the mismanagement of capture fisheries (Black and Hughes, 2017; Barange, 2019).

Generally, the projected impact of climate change on agriculture and capture fisheries is expected to lower the availability and increase the cost of the inputs, such as fish seed and feed ingredients required for aquaculture production. Consequently, aquaculture production costs are expected to rise, making it more difficult, especially for small-scale producers to survive in the sector. On the other hand, the rising fishmeal and fish oil prices are likely to accelerate developments in scientific studies that seek to identify alternative protein and oil sources to replace conventional ingredients in aquafeeds (Hardy, 2010). Recently, plant proteins, mainly oilseeds from agriculture have attracted considerable attention for use in aquaculture protein sources. Today, the need to replace fishmeal and fish oils with alternative ingredients in feed formulations has become an important developmental agenda aimed at sustaining the aquaculture sector.

\section{Changes in Sea Surface Salinity}

Salinity is seen as a variable parameter reflecting the input of freshwater from precipitation, ice melting, river runoff, loss of water through evaporation, and the mixing and circulation of ocean surface water with underground water (Koblinsky et al., 2003; Cochrane et al., 2009). Variations in sea salinity may occur due to increased evaporation resulting from rising temperature and ocean circulation changes or induced directly by climate change (Cooper, 1988; Robinson et al., 2005). These variations may affect oceanic circulation and stratification, and hence, the ocean's capacity to store heat, and carbon and nutrient circulation (Seggel et al., 2016). Since climate change is expected to cause these variations, the environmental sustainability of aquaculture will be affected. Most aquatic organisms have specific salinity levels within which they can survive, any alterations may lead to mortalities and production losses (Jahan et al., 2019). In stripped catfish, salinity levels above optimal requirements have been reported to cause reduced survival, growth, and red blood cells, suggesting an effect on the fish's immune system (Jahan et al., 2019). Meaning that variations in sea salinity are expected to negatively affect the economic gains for some aquaculture species which could affect the social and economic aspects of aquaculture production sustainability negatively. However, the higher salinity effect has been strongly correlated with aquaculture production systems in downstream regions of coastal areas (Nguyen et al., 2018). For example, Ahmed (2013), reported negative effects on the production performance of freshwater prawns at higher salinity. Baker et al. (2005) reported increased mortality in juvenile clams, while (Rodrick, 2008) reported increased susceptibility to bacterial invasion in oysters at lower water salinity. Furthermore, Rodrick (2008) observed that variations in salinity may affect the immune system of oysters, particularly the ability of hemocytes (blood cells) to resist foreign bacterial invasion. Although compared to other marine mollusks, clams are reported to have a wider tolerance to salinity, Baker et al. (2013) noted that they cannot endure prolonged exposure to either high or low salinity. Increased mortalities of abalone in farms, particularly those operating in coastal areas have also been predicted under a changing climate through the intrusion of saline water from marine environments (Morash and Alter, 2015). In general, variation in water salinity will lead to increased mortalities for several species which may affect the economic and social sustainability of the sector through increased species' losses and higher management costs.

However, the majority of the current knowledge on the effect of climate-related changes on salinity in aquaculture has been biased toward reporting the effect of higher salinity. There is a need for studies that focus on the effect of salinity levels lower than an optimal requirement on finfish and shellfish. Furthermore, the response of several species of commercial importance to climate-induced salinity changes is poorly understood. This information is especially useful for adaptation in aquaculture, as changes in salinity may favor the cultivation of tolerant species (Jahan et al., 2019).

\section{Severe Climatic Events}

Severe climatic events, such as cyclones, waves, and storms are expected to influence aquaculture development especially marine ornamental products, and those in coastal areas (Toussaint et al., 2018). For example, the coral and giant clam farmers in tropical villages may face the risk of increased losses as a result of bleaching, while those in sub-tropical regions are likely to suffer greater risks, such as loss of production equipment and stock due to rougher sea conditions related to stronger cyclones (Hamdan et al., 2012). The occurrence of storm surges, waves, and coastal 
erosion are considered the most dangerous threats to aquaculture production and other related coastal activities (Hamdan et al., 2012). Severe storms will result in high losses to the farmers due to damage on farms resulting in higher costs of recovering the damaged activities (Canadian Institute for Climate Studies, 2000). For instance, cage aquaculture will likely face higher risks from the effects of cyclones and waves. The increased storminess projected for certain seasons in certain regions may also increase the risk of aquatic organism escapes due to equipment failure and may require site relocation or changes in production practices which may seriously affect the social and economic sustainability of aquaculture in these areas (Gubbins et al., 2013). According to Barange et al. (2018), severe climatic events are reported to have increased in several regions in the recent past and are represented by at least $80 \%$ of all climate-related disasters. However, these events are predicted to occur more frequently in Africa, particularly in East and Southern Africa (IPCC, 2019).

On the other hand, severe climatic events, such as storms will likely play a significant role in mixing water columns and nutrients that have previously been restricted to certain columns due to thermal stratification (Seggel et al., 2016) which could promote the environmental sustainability of aquaculture production. Moreover, storms may be very crucial in decreasing water temperatures and associated risks that may harm both cultured and wild organisms (Seggel et al., 2016).

\section{MITIGATION AND ADAPTATION OPTIONS}

Climate change-related risks to health, food security, livelihood, water supply, human security, and economic development will increase under the projected $1.5^{\circ} \mathrm{C}$ global warming, with a further increase expected at $2^{\circ} \mathrm{C}$ (IPCC, 2018). In the face of such risks, both the industry and communities will need to mitigate and adapt to the changing climate by taking advantage of new opportunities emerging from altered resources (Lorenzen et al., 2017). Mitigation and adaptation may help prepare the farming communities, ecosystems, and populations, in general, to build resilience and deal with climate change as effectively and efficiently as possible (Zolnikov, 2019). Mitigation focuses on reducing or reversing the rate of climate change (Leal Filho, 2011; ACT, 2018). This involves mainly reducing GHGs emission with a special focus on $\mathrm{CO}_{2}$ emissions which accounts for more than $60 \%$ of human enhanced increases (Mohanty et al., 2010; IPCC, 2014; Environmental Protection Agency, 2016). According to the IPCC (2018), reductions in $\mathrm{CO}_{2}$ emissions may be achieved through a combination of new and existing technologies and practices, including electrification, hydrogen, sustainable bio-based feedstocks, product substitution, and carbon capture utilization and storage. In aquaculture, producers and other stakeholders may play a significant role in mitigating climate change effects by making necessary adjustments in their production practices aimed at minimizing the emission of GHGs. Specifically, this includes the use of environmentally friendly practices and technology, such as solar energy, proper feeding practices, and sustainable wastewater management to minimize air and water pollution (VGREEN, 2012; Barange et al., 2018). Feed production in aquaculture is particularly seen as the sector's major contributor to GHG emissions (VGREEN, 2012). For example, the use of sinking feeds is reported to be more environmentally friendly compared with floating feeds (Hardy, 2010; VGREEN, 2012). However, mitigation is a longterm solution to climate change whose benefits may take a significant amount of time to be realized (Elum et al., 2017; ACT, 2018). Besides, effective mitigation requires collective action on a global scale since most GHGs accumulate over time and mix globally, resulting in a global effect (IPCC, 2014). Therefore, it is suggested that mitigation be implemented hand in hand with adaption strategies for better and effective results (ACT, 2018; IPCC, 2019).

Adaptation focuses on building resilience to the consequences, and the capacity to utilize emerging opportunities sustainably and ethically (Bueno and Soto, 2017). It involves making considerations in advance, the expected changes, and taking those changes into account in short-term decision making and long-range planning (Yazdi and Shakouri, 2010). Therefore, it can come in various forms, including technical changes, changes in the behavior of resource users/producers, or changes in the governance system (Lorenzen et al., 2017). Moreover, FAO (2018) provides three target areas upon which successful adaptation interventions may be centered, namely: institutions and management, livelihood adaptation, and resilience and risk reduction. However, a combination of these areas may most likely yield better results compared to a single area focus looking at the strong link that exists among them and their complementary action. Currently, adaptation is seen as the most viable option at the producers' disposal to cope with the effects of climate change on aquaculture (Yazdi and Shakouri, 2010). Moreover, IPCC (2014) noted that adaptation experience to climate change effects continues to rise across regions in both the public and private sectors, becoming more recognized and included in developmental plans by several governments. Furthermore, adaptation options that can also be used for mitigating GHG emissions are more recommended since they can offer synergies that may lead to reduced costs in many sectors (IPCC, 2018). Most importantly, adaptation is not a onesize-fits-all situation, considering the dynamics of vulnerability and exposure, and their linkage with the socio-economic and sustainable development of various sectors (IPCC, 2014, 2018; Clements and Chopin, 2016; Zolnikov, 2019). According to the IPCC (2018), successful adaptation in a changing climate will depend on the adaptive capacity of the producers in a given nation or region. For example, more severe effects have been predicted on the producers in developing countries due to low adaptive capacity (Figure 2) (Handisyde et al., 2017; Barange et al., 2018; IPCC, 2018; King and Harrington, 2018; Zolnikov, 2019). Although adaptation options are more likely to be effective and sustainable if selected according to a country's context and enabling environments (Bradley et al., 2015; Blanchard et al., 2017; IPCC, 2018), we have highlighted some options that may have a global application (Table 2).

Diversification of livelihoods may be one of the keys to successful adaptation because it gives the producers options from 


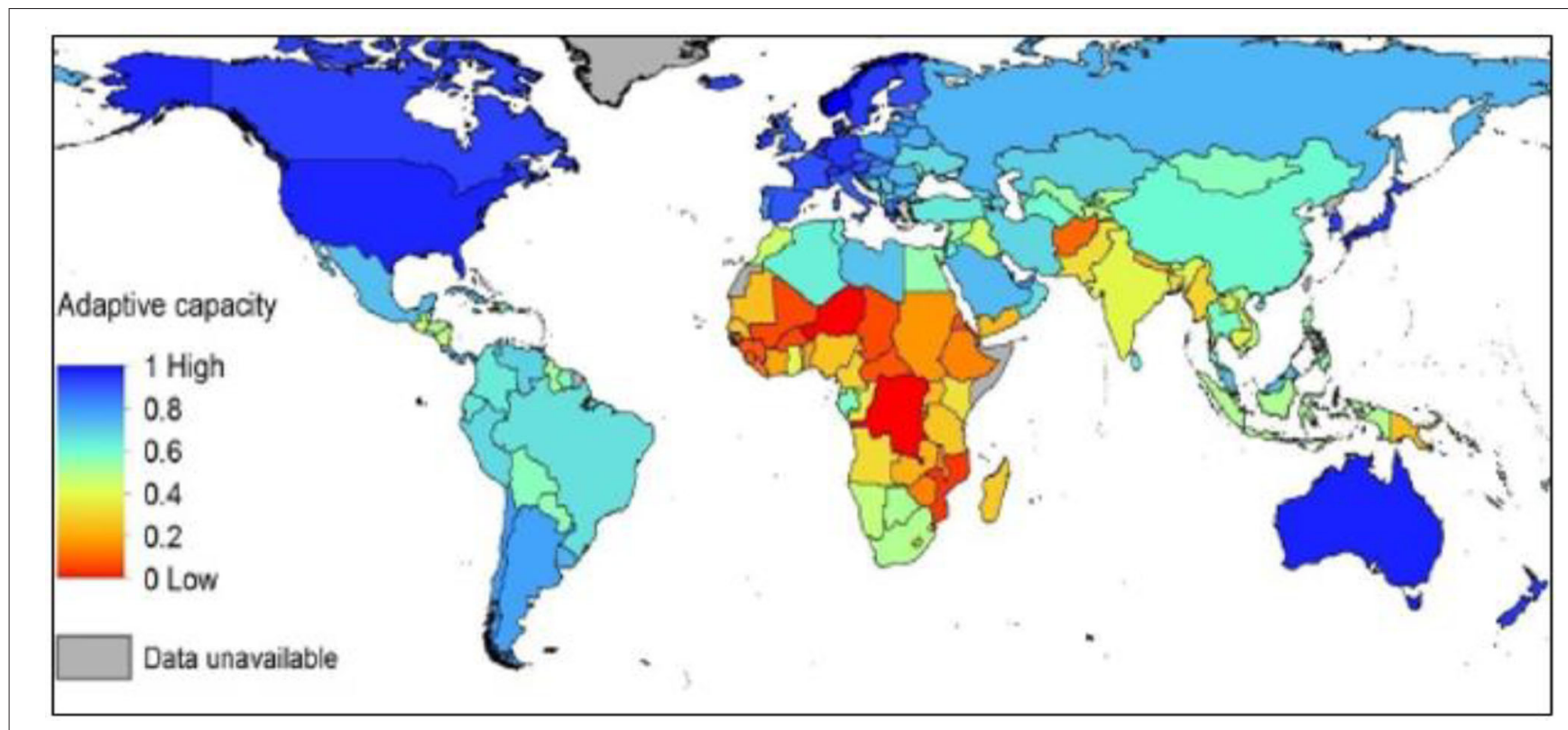

FIGURE 2 | World map showing the adaptive capacity of the nations to climate change effects on aquaculture. Source: Handisyde et al. (2017).

TABLE 2 | Some adaptation options to climate change effects on aquaculture that may be applied in many regions globally.

\begin{tabular}{ll}
\hline Adaptation option & References \\
\hline Livelihood diversification & Bell et al., 2013; Blanchard et al., \\
& 2017; Duarte et al., 2017; \\
& Zolnikov, 2019 \\
Shifting to less vulnerable or more resilient & De Young et al., 2012; \\
species, techniques, or regions. May also & Lim-Camacho et al., 2014; \\
include selective breeding for more & Sae-Lim et al., 2017; Dabbadie \\
resistant aquaculture species & et al., 2018 \\
Enhancing the effective management of & Frusher et al., 2013; Malcorps \\
capture fisheries & et al., 2019 \\
Utilization of local and indigenous & Leal Filho, 2011; IPCC, 2014; \\
knowledge & Magrin et al., 2014; Shelton, \\
& 2014; Makondo and Thomas, \\
& 2018 \\
Introduction and promotion of insurance & Shelton, 2014; Pongthanapanich \\
schemes among the producers especially & et al., 2016; Barange et al., 2018 \\
small-scale farmers &
\end{tabular}

which they can derive their livelihoods and build appropriate resilience from climate change impacts (Bell et al., 2013; Duarte et al., 2017; Zolnikov, 2019). It involves combining aquaculture production systems with other sectors, such as agricultural systems, either integrated or as separate systems. Diversifying livelihood sources is extremely useful, especially in some regions or countries where fish production is predicted to decline, while agricultural production is expected to increase (Blanchard et al., 2017). However, successful diversification requires that government policies provide incentives for efficient utilization of resources, equity, and protection of the environment (Troell et al., 2014). Moreover, improving livelihood diversification among aquaculture producers requires integrating indigenous knowledge with government interventions (Leal Filho, 2011). Unfortunately, the major factor affecting the adaptive capacity of farmers, households, and communities at large is their access to, control over, and ability to use productively the natural, human, social, physical, and financial assets, i.e., the livelihood capital (Bueno and Soto, 2017).

Aquaculture producers may also benefit from shifting to aquaculture species, techniques, or areas that are less vulnerable or are more resilient to a changing environment and resources (Lim-Camacho et al., 2014). For example, Integrated MultiTrophic Aquaculture (IMTA) system is more environmentally friendly, sustainable, and economically rewarding as well as more resilient to changing climate compared to monoculture because it combines finfish farming with other species (Osch et al., 2019). Aquaculture producers may also make use of altered resources, such as land by practicing new farming systems. Furthermore, shifting to or developing aquaculture species that are more resilient to climate change is one of the most promising areas for adaptation (De Young et al., 2012). For example, Sae-Lim et al. (2017) noted that selection of species based on feed efficiency and defining a breeding goal that minimizes the emission of GHGs will play a key role in a changing climate. However, this requires the consideration of the environmental and social benefits of communities compared to focusing on short-term economic benefits (Olesen et al., 2000). Further, it is important to note that there will be costs, such as research and development associated with developing new aquaculture species (Harvey et al., 2017).

Another way of adapting to climate change among the aquaculture producers is by ensuring a continued supply of fish from capture fisheries by promoting changes in fishers' behavior, changes in governance, as well as the use of effective management 
plans and strategies. For example, applying changes to the management of the tradable quota allocated to individual fishers (Frusher et al., 2013). Besides, there is a need to incorporate climate variability and change in the modeling of aquaculture undertakings to reduce the impacts of climate change in fisheries-based livelihoods. According to FAO (2020), global production from capture fisheries has stagnated or declined in some years over the past few decades. The ever-increasing global population and the consequential rising demand for aquatic products are considered the primary cause of dwindling production from capture fisheries (Maulu and Musuka, 2018). Currently, aquaculture production heavily relies on resources from capture fisheries, such as fishmeal, fish oils, broodstocks, and wild seeds as crucial production inputs (Laffoley, 2013; FAO, 2018; Malcorps et al., 2019). Therefore, effective management of resources from fisheries may contribute to a sustainable supply of aquaculture inputs.

The utilization and incorporation of local and indigenous knowledge in adaptation strategies have also been shown to offer effective adaptation to climate change (Leal Filho, 2011; IPCC, 2014; Magrin et al., 2014; Makondo and Thomas, 2018). While scientific understanding provides a generalized insight regarding climate change and its potential effects, indigenous knowledge may provide specific details about the physical environment, infrastructure systems, livelihood status, behavior, governance organization, and other attributes that are crucial for managing community resources (Kettle et al., 2014). For example, the use of traditional methods and indicators to predict changes in weather patterns (temperature, rainfall, humidity, etc.) may help the producers prepare for expected changes and build resilience (Zolnikov, 2019). Information on how such incorporation has been utilized in aquaculture production is still largely unknown. However, in other sectors, such as agriculture, it has successfully been used by farming communities. A good example is in Kenya, where indigenous knowledge helped some farming communities prepare for climate change effects and reduce susceptibility to food insecurity (Leal Filho, 2011). Moreover, the integration of indigenous knowledge with scientific knowledge may be one of the most powerful tools for strengthening other adaptation strategies, despite having been overlooked (Kettle et al., 2014; Belfer et al., 2017; Lesperance, 2017; Makondo and Thomas, 2018).

Another growing area that may be considered for adaptation is building adaptive capacity in aquaculture, especially for smallscale producers through insurance schemes. Most climate change predictions indicate that small-scale producers will be the most affected due to poor adaptive capacity (IPCC, 2014; Bueno and Soto, 2017; Barange et al., 2018). Hence, an insurance scheme could help them build resilience. Generally, insurance for aquaculture producers globally is still relatively new despite gaining considerable attention (Pongthanapanich et al., 2016). In Vietnam, a pilot project conducted between 2011 and 2013 showed that farmers had a very poor understanding of the scheme which led to poor results (Pongthanapanich et al., 2016), suggesting that awareness among other measures may lead to better results. Insurance schemes may especially be useful for producers with poor adaptive capacity for building resilience against the effects of climate change (Barange et al., 2018). However, the viability of the aquaculture insurance business may depend on how efficient and lower-risk aquaculture becomes, apart from climate change risks (Barange et al., 2018). Being a relatively new subject in aquaculture, there is a need for investigations to expound its benefits and implications on the economic conditions of the farmers, especially among the most vulnerable communities.

\section{Challenges to Successful Adaptation and Proposed Strategies}

Although adaptation is considered the most viable short-term solution to climate change, its implementation may face several challenges. For example, failure to acknowledge the fact that climate change will affect the producers differently based on their specific region, environment, knowledge regarding climate change, population, community dynamics, economic conditions, and present industry (Marshall et al., 2009). Unless these factors are taken into account, adaptation strategies will probably be of little benefit to the producers and stakeholders in the aquaculture sector (Zolnikov, 2019). To address this, there is a need for governments, especially in more vulnerable countries, to ensure that policy formulations related to climate change interventions recognize this fact to meet producer needs in their specific situation. Therefore, more efforts and resources should be directed toward the most vulnerable producer groups. Also, as observed by Lorenzen et al. (2017) adaptation is more likely to be successful if producers are made aware of the drivers and impact pathways, monitoring a broad suite of impact indicators, and adaptive decision-making. In recent years, several models have been used to predict the impacts of climate change on food production systems including aquaculture (Rosenzweig et al., 2014; Saba et al., 2016; Tiller et al., 2016; Blanchard et al., 2017; Galbraith et al., 2017). However, wrong projections may affect successful adaptation to climate change effects by the aquaculture producers. The capacity of the producers to adapt to climate change will likely depend on accurate future projections against different systems of the aquaculture sector. Unrealistic and biased estimation of the potential risks associated with climate change may mislead policymakers and the aquaculture producers in taking necessary precautions. The consequences of maladaptation include increased future vulnerability and/or exposure of the target community, region, or sector to climate change effects (IPCC, 2014). To address biases of climate models, Palmer and Stevens (2019) note that there is a need to reduce the dependence of these models on subgrid parameterizations as much as possible and if not, then report their uncertainty. The authors further suggest that future models should be sustainable and cutting across nations, embracing the high-performance application of computing and technology. Another challenge to successful adaptation is the capacity of producers in terms of preparedness. For example, some regions of the world, such as those in western countries, are more equipped in terms of governance, incomes, technology, human capital, and social networks than those in sub-Saharan African countries (Zolnikov, 2019). Besides, several projections 
show that aquaculture producers in developing countries will be the most affected and this is due to poor adaptive capacity (Barange et al., 2018; Zolnikov, 2019). Therefore, IPCC (2018) strongly recommends international cooperation that promotes enhanced access to finances and technology and enhanced local capacities for developing nations and most vulnerable regions for effective action. Finally, it is now becoming clearer that the entire aquaculture value chain is vulnerable to climate change effects. However, much of the currently available literature focuses more on the production system leaving out other stages, such as trade and marketing of aquatic products. Such a narrow focus of scientific studies limits our understanding of the extent to which the aquaculture sector will be affected and hence, adaptation options. Therefore, future studies and models should have a broader focus and encompass all stages of the aquaculture value chain.

\section{CONCLUSION AND PROSPECTS}

This review has highlighted the potential effects of climate change on aquaculture production and implications on the sector's sustainability. Despite being considered the only solution to meeting the continued rise in demand for aquatic products globally, the aquaculture sector is increasingly being threatened by human-driven climate change effects that are both a present and future reality. These effects on aquaculture are expected to be both positive and negative, although the negative outweighs the positive ones. Besides, although climate change is a global food production risk, the associated risks on aquaculture are expected to differ across geographical or climatic zones, national economy, water environment, production systems, the scale of production, and cultured species of the aquaculture producers. To build resilience and sustain production in a changing climate, the aquaculture producers must adapt to the available options in the short-term while mitigating the effects by making necessary adjustments in their production practices in the long-term. This review has addressed important aspects of climate change and aquaculture production; however, several limitations were identified that presents important areas

\section{REFERENCES}

ACT (2018). Mitigation, Adaptation, and Resilience: Climate Terminology Explained. Retrieved from: https://www.hidropolitikakademi.org/tr/news/ 22267/mitigation-adaptation-and-resilience-climate-terminology-explained

Adhikari, S., Keshav, C. A., Barlaya, G., Rathod, R., Mandal, R. N, Ikmail, S., et al. (2018). Adaptation and mitigation strategies of climate change impact in freshwater aquaculture in some states of India. J. Fish. 12, 016-021.

Ahmed, N. (2013). Linking prawn and shrimp farming towards a green economy in Bangladesh: confronting climate change. Ocean Coast. Manage. 75, 33-42. doi: 10.1016/j.ocecoaman.2013. 01.002

Ahmed, N., Thompson, S., and Glaser, M. (2019). Global aquaculture productivity, environmental sustainability, and climate change adaptability. Environ. Manage. 63:159. doi: 10.1007/s00267-0181117-3

Akegbejo-Samsons, Y. (2009). Climate change impacts on fisheries production in land-water interface. IOP Conf. Ser. Earth Environ. Sci. 6:292022. doi: $10.1088 / 1755-1307 / 6 / 29 / 292022$ for future consideration. For example, the review is limited to production and input supply stages of the aquaculture value chain and does not address the other important stages, such as trade, processing, and consumption of the products. In addition, within the production stage of the value chain discussed, it was not clear how various species of economic importance at different life stages will respond to a changing climate. Information on this would be useful for adaptation strategies that may require the producers to shift to species that may be more resilient to the change in the climate. Also, there were few practical examples of the implication climate change is expected to have on aquaculture production sustainability, and in most cases, studies were biased toward environmental dimensions of sustainability while neglecting the social and economic aspects. As the aquaculture sector continues to grow while climate change becomes clearer, there is a need to embrace a holistic approach in projecting climate change effects on aquaculture and in addressing these impacts. Consequently, mitigation and adaptation strategies would be more effective. However, this will require developments in research, especially in more vulnerable regions due to poor adaptive capacity. Therefore, poorer economies could benefit more from international cooperation.

\section{AUTHOR CONTRIBUTIONS}

SM generated the idea, defined the objectives and coordinated the writing of the manuscript. OJH assisted in defining the objectives and participated in writing the manuscript. LHH, CM, and CGM critically reviewed and made substantial contributions to the manuscript. THM, BPM, and KJP participated in writing the manuscript. JDM revised the conception of the manuscript. All the authors read and approved the final manuscript.

\section{ACKNOWLEDGMENTS}

The authors would like to sincerely thank all the institutions represented by the authors for working together toward a common goal.
Asiedu, B., Malcolm, D., and Iddrisu, S. (2019). Assessing the economic impact of climate change in the small-scale aquaculture industry of Ghana, West Africa. AAS Open Res. 1:26. doi: 10.12688/aasopenres.12911.2

AskarySary, A., Velayatzadeh, M., and KarimiSary, V. (2012). Proximate composition of farmed fish, Oncorhynchus mykiss and Cyprinus carpio from Iran. Adv. Environ. Biol. 6, 2841-2845.

Bahri, T., Barange, M., and Moustahfid, H. (2018). "Chapter 1: climate change and aquatic systems," in Impacts of Climate Change on Fisheries and Aquaculture, Synthesis of Current Knowledge, Adaptation and Mitigation Options, eds M. Barange, T. Bahri, M. C. M. Beveridge, K.L. Cochrane, S. Funge-Smith, and F. Poulaine (Rome: FAO), 1-17.

Baker, S., Hoover, E., and Sturmer, L. (2013). The Role of Salinity in Hard Clam Aquaculture. Gainesville, FL: University of Florida.

Baker, S. M., Baker, P., Heuberger, D., and Sturmer, L. (2005). Short-term effects of rapid salinity reduction in seed clams (Mercenaria, Mercenaria). J. Shellfish Res. 24, 29-33. doi: 10.2983/0730-8000(2005)24[29:SEORSR]2.0.CO;2

Barange, M. (2019). Avoiding misinterpretation of climate change projections of fish catches, food for thought. ICES J. Mar. Sci. 76, 1390-1392. doi: 10.1093/icesjms/fsz061 
Barange, M., Bahri, T., Beveridge, M. C. M., Cochrane, A. L., Funge-Smith, S., and Paulain, F. (2018). Impacts of Climate Change on Fisheries and Aquaculture, Synthesis of Current Knowledge, Adaptation and Mitigation Options. Rome: FAO.

Basti, L., Endo, M., and Segawa, S. (2011). Physiological, pathological, and defense alterations in Manila clams (short-neck clams), Ruditapes philippinarum, induced by Heterocapsa circularisquama. J. Shellfish Res. 30, 829-844. doi: 10.2983/035.030.0324

Basti, L., Nagai, K., Segawa, S., Tanaka, Y., Toshiyuki Suzuki, T., and Nagai, S. (2019). Harmful algal blooms and shellfish aquaculture in changing environment. Bull. Jpn. Fish. Res. Educ. Agen. No. 49, 73-79.

Beach, R. H., and Viator, C. L. (2008). The economics of aquaculture insurance: an overview of the U.S. pilot insurance program for cultivated clams. Aquac. Econ. Manage. 12, 25-38. doi: 10.1080/13657300801959613

Belfer, E., Ford, J. D., and Maillet, M. (2017). Representation of Indigenous peoples in climate change reporting. Clim. Change 145:57. doi: 10.1007/s10584-017-2076-Z

Bell, J., Batty, M., Ganachaud, A., Gehrke, P., Hobday, A., Hoegh-Guldberg, O., et al. (2010). "Preliminary assessment of the effects of climate change on fisheries and aquaculture in the Pacific," in Fisheries in the Economies of the Pacific Island Countries and Territories. Pacific Studies Series, ed R. Gillett (Manila: Asian Development Bank), 451-469.

Bell, J. D., Ganachaud, A., Gehrke, P. C., Griffiths, S. P., Hobday, A. J., Hoegh-Guldberg, O., et al. (2013). Mixed responses of tropical Pacific fisheries and aquaculture to climate change. Nat. Clim. Change 3, 591-599. doi: $10.1038 /$ nclimate 1838

Beveridge, M. C. M., Dabbadie, L., Soto, D., Ross, L. G., Bueno, P. B., and AguilarManjarrez, J. (2018). Chapter 22: Climate Change and Aquaculture: Interactions With Fisheries and Agriculture. Rome: FAO.

Black, K., and Hughes, A. (2017). Future of the Sea: Trends in Aquaculture, Foresight-Future of the Sea Evidence Review Foresight. Edinburgh: Government Office for Science.

Blanchard, J. L., Watson, R. A., Fulton, E. A., Cottrell, R. S., Nash, K. L., BryndumBuchholz, A., et al. (2017). Linked sustainability challenges and trade-offs among fisheries, aquaculture and agriculture. Nat. Ecol. Evol. 1, 1240-1249. doi: 10.1038/s41559-017-0258-8

Bradley, M., Putten, I., and Sheaves, M. (2015). The pace and progress of adaptation: marine climate change preparedness in Australia's coastal communities. Mar. Policy 53, 13-20. doi: 10.1016/j.marpol.2014.11.004

Brander, K. M. (2007). Global fish production and climate change. Proc. Natl. Acad. Sci. U.S.A. 104, 19709-19714. doi: 10.1073/pnas.0702059104

Brodie, J., Williamson, C. J., Smale, D. A., Kamenos, N. A., Mieszkowska, N., Santos, R., et al. (2014). The future of the northeast Atlantic benthic flora in a high $\mathrm{CO}_{2}$ world. Ecol. Evol. 4, 2787-2798. doi: 10.1002/ece3.1105

Bueno, P. B., and Soto, D. (2017). Adaptation Strategies of the Aquaculture Sector to the Impacts of Climate Change. Rome: FAO.

Canadian Institute for Climate Studies (2000). Aquaculture and Climate Change in Canada: A Discussion Paper. Ottawa, ON: Canadian Institute for Climate Studies.

Chan, F. T., Stanislawczyk, K., Sneekes, A. C., Dvoretsky, A., Gollasch, S., Minchin, D., et al. (2019). Climate change opens new frontiers for marine species in the Arctic: current trends and future invasion risks. Glob. Change Biol. 25, 25-38. doi: $10.1111 /$ gcb.14469

Cheung, W. W. L., Watson, R., and Pauly, D. (2013). Signature of ocean warming in global fisheries catch. Nature 497, 365-369. doi: 10.1038/nature 12156

Chiaramonte, L., Munson, D., and Trushenski, J. (2016). Climate Change and Considerations for Fish Health and Fish Health Professionals. Fish Health Section, Fisheries. Available online at: www.fisheries.org

Chung, I. K., Oak, J. H., Lee, J. A., Shin, J. A., Kim, J. G., and Park, K. S. (2013). Installing kelp forest/seaweed beds for mitigation and adaptation against global warming: Korean Project overview. ICES J. Mar. Sci. 70, 1038-1044. doi: 10.1093/icesjms/fss206

Chung, I. K., Sondak, C. F. A., and Beardall, J. (2017). The future of seaweed aquaculture in a rapidly changing world. Eur. J. Phycol. 52, 495-505. doi: 10.1080/09670262.2017.1359678

Clements, J. S., and Chopin, T. (2016). Ocean acidification and marine aquaculture in North America: potential impacts and mitigation strategies. Rev. Aquac. 9, 326-341. doi: 10.1111/raq.12140
Cochrane, K., De Young, C., Soto, D. T., and Bahri, D. T. (2009). Climate Change Implications for Fisheries and Aquaculture: Overview of Current Scientific Knowledge. FAO Fisheries and Aquaculture Technical Paper No. 530. Rome: FAO.

Collins, C., Bresnan, E., Brown, L., Falconer, L., Guilder, J., Jones, L., et al. (2020). Impacts of climate change on aquaculture. MCCIP Sci. Rev. 2020, 482-520. doi: 10.14465/2020.arc21.aqu

Cook, D., and Zolnikov, T. R. (2019). “Antarctica," in Global Adaptation and Resilience to Climate Change, Palgrave Studies in Climate Resilient Societies, ed T. R. Zolnikov (Bern; Cham: Palgrave Pivot), 31-49. doi: 10.1007/978-3-030-01213-7_1

Cooley, S. R., Lucey, N., Kite-Powell, H., and Doney, S. C. (2012). Nutrition and income from molluscs today imply vulnerability to ocean acidification tomorrow. Fish Fish. 13, 182-215. doi: 10.1111/j.1467-2979.2011. 00424.x

Cooper, N. S. (1988). The effect of salinity on tropical ocean models. J. Phys. Oceanogr. 18, 697-707. doi: 10.1175/1520-0485(1988)018<0697:TEOSOT $>2.0$. $\mathrm{CO} ; 2$

Cornwall, C. E., Hepburn, C. D., Pritchard, D., Currie, K. I., McGraw, C. M., Hunter, K. A., et al. (2012). Carbon use strategies in macroalgae: differential responses to lowered $\mathrm{pH}$ and implications for ocean acidification. J. Phycol. 48, 137-144. doi: 10.1111/j.1529-8817.2011.01085.x

Dabbadie, L., Aguilar-Manjarrez, J. J., Beveridge, M. C. M., Bueno, P. B., Ross, L. G., and Soto, D. (2018). Chapter 20: Effects of Climate Change on Aquaculture: Drivers, Impacts and Policies. Rome: FAO.

Daw, T., Adger, W. N., Brown, K., and Badjeck, M. C. (2009). "Climate change and capture fisheries: potential impacts, adaptation and mitigation," in Climate Change Implications for Fisheries and Aquaculture: Overview of Current Scientific Knowledge. FAO Fisheries and Aquaculture Technical Paper. No. 530, eds K. Cochrane, C. De Young, D. Soto, and T. Bahri (Rome: FAO), 107-150.

De Silva, S. S., and Soto, D. (2009). "Climate change and aquaculture: potential impacts, adaptation and mitigation," in Climate Change Implications for Fisheries and Aquaculture: Overview of Current Scientific Knowledge. FAO Fisheries and Aquaculture Technical Paper. No. 530, eds K. Cochrane, C. De Young, D. Soto, and T. Bahri (Rome: FAO), 151-212.

De Young, C., Soto, D., Bahri, T., and Brown, D. (2012). "Building resilience for adaptation to climate change in the fisheries and aquaculture sector," in Proceedings of a Joint FAO/OECD Workshop, eds A. Meybeck, J. Lankoski, S. Redfern, N. Azzu, and V. Gitz (Rome).

Doney, S. C., Ruckelshaus, M., Duffy, J. E., Barry, J. P., Chan, F., English, C. A., et al. (2012). Climate change impacts on marine ecosystems. Annu. Rev. Mar. Sci. 4, 11-37. doi: 10.1146/annurev-marine-041911-111611

Doubleday, Z. A., Clarke, S. M., Li, X., Pecl, G. T., Ward, T. M., Battaglene, S., et al. (2013). Assessing the risk of climate change to aquaculture: a case study from south-east Australia. Aquacult. Environ. Interact. 3, 163-175. doi: 10.3354/aei00058

Duarte, C. M., Wu, J., Xiao, X., Bhrun, A., and Krause-Jensen, D. (2017). Can seaweed farming play a role in climate change mitigation and adaptation? Fronti. Mar. Sci. 4:100. doi: 10.3389/fmars.2017.00100

Edwards, M., Johns D. G., Leterme S. C., Svendsen E., and Richardson A. J. (2006). Regional climate change and harmful algal blooms in the NE Atlantic. Limnol. Oceanogr. 51, 820-829. doi: 10.4319/lo.2006.51.2.0820

Edwards, M., and Richardson, A. J. (2004). Impact of climate change on marine pelagic phenology and trophic mismatch. Nature 430, 881-884. doi: $10.1038 /$ nature 02808

Ellis, R. P., Urbina, M. A., and Wilson, R. W. (2017). Lessons from two high $\mathrm{CO}_{2}$ worlds-future oceans and intensive aquaculture. Glob. Change Biol. 23, 2141-2148. doi: 10.1111/gcb.13515

Elum, Z. A., Modise, D. M., and Marr, A. (2017). Farmer's perception of climate change and responsive strategies in three selected provinces of South Africa. Clim. Risk Manage. 16, 246-257. doi: 10.1016/j.crm.2016.11.001

Engle, C. R. (2019). Bringing aquaculture sustainability down to earth. J. World Aquac. Soc. 50, 246-248. doi: 10.1111/jwas.12609

Environmental Protection Agency (2016). Sources of Greenhouse Gas Emissions. Retrieved from: https://www.epa.gov/ghgemissions/sources-greenhousegasemissions

FAO (2018). The State of World Fisheries and Aquaculture 2018: Contributing to Food Security and Nutrition for All. Rome: FAO. 
FAO (2020). The State of World Fisheries and Aquaculture 2020. Sustainability in Action. Rome: FAO.

Farrell, H., Seebacher, F., O’Connor, W., Zammit, A., Harwood, D. T., and Murray, S. (2015). Warmer temperature acclimation impacts metabolism of paralytic shellfish toxins from Alexandrium minutum in commercial oysters. Glob. Chang.Biol. 21, 3402-3413. doi: 10.1111/gcb.12952

Ficke, A. D., Myrick, C. A., and Hansen, L. J. (2007). Potential impacts of global climate change on freshwater fisheries. Rev. Fish Biol. Fish. 17, 581-613. doi: 10.1007/s11160-007-9059-5

Fleming, A., Hobday, A. J., Farmery, A., van Putten, E. I., Pecl, G. T., Green, B. S., et al. (2014). Climate change risks and adaptation options across Australian seafood supply chains-a preliminary assessment. Clim. Risk Manage. 1, 39-50. doi: 10.1016/j.crm.2013.12.003

Franke, A., and Clemmesen, C. (2011). Effect of ocean acidification on early life stages if Atlantic herring (Clupea harengus L.). Biogeosciences 8, 3697-3707. doi: 10.5194/bg-8-3697-2011

Freeman, E. O. (2017). Impact of climate change on aquaculture and fisheries in Nigeria: a review. Int. J. Multidiscipl. Res. Dev. 4, 53-59.

Froehlich, H. E., Gentry, R. R., and Halpern, B. S. (2017). Conservation aquaculture: shifting the narrative and paradigm of aquaculture's role in resource management. Biol. Conserv. 215, 162-168. doi: 10.1016/j.biocon.2017.09.012

Froehlich, H. E., Gentry, R. R., and Halpern, B. S. (2018). Global change in marine aquaculture production potential under climate change. Nat. Ecol. Evol. 2, 1745-1750. doi: 10.1038/s41559-018-0669-1

Frommel, A. Y., Maneja, R., Lowe, D., Malzahn, A. M., Geffen, A. J., Folkvord, A., et al. (2012). Severe tissue damage in Atlantic cod larvae under increasing ocean acidification. Nat. Clim. Change 2, 42-46. doi: 10.1038/nclimate1324

Frommel, A. Y., Maneja, R., Lowe, D., Pascoe, C. K., Geffen, A. J., Folkvord, A., et al. (2014). Organ damage in Atlantic herring larvae as a result of ocean acidification. Ecol. Appl. 24, 1131-1143. doi: 10.1890/13-0297.1

Frusher, S. D., Hobday, A. J., Jennings, S. M., Crighton, C., De Silva, S., Pecl, G. T., et al. (2013). The short history of a marine hotspot-from anecdote to adaptation in south-east Australia. Rev. Fish. Biol. Fish. 24, 593-611. doi: $10.1007 /$ s11160-013-9325-7

Galbraith, E. D., Carozza, D. A., and Bianchi, D. (2017). A coupled humanEarth model perspective on long-term trends in the global marine fishery. Nat. Commun. 8:14884 doi: 10.1038/ncomms14884

Gao, Y., Yu, G., Yang, T., Jia, Y., He, N., and Zhuang, J. (2016). New insight into global blue carbon estimation under human activity in landsea interaction area: a case study of China. Earth Sci. Rev. 159, 36-46. doi: 10.1016/j.earscirev.2016.05.003

Gazeau, F., Alliouane, S., Bock, C., Bramanti, L., Gentille, M., Hirse, T., et al. (2014). Impact of ocean acidification and warming on the Mediterranean mussel (Mytilus galloprovincialis). Front. Mar. Sci. 1:62. doi: 10.3389/fmars.2014.00062

Gubbins, M., Bricknell, I., and Service, M. (2013). Impacts of climate change on aquaculture. MCCIP Sci. Rev. 2013, 318-327. doi: 10.14465/2013.arc33.318-327

Guyondet, T., Comeau, L. A., Bacher, C., Grant, J., Rosland, R., Sonier, R., et al. (2018). Climate change influences carrying capacity in a coastal embayment dedicated to shellfish aquaculture. Estuar. Coasts 38, 1593-1618. doi: 10.1007/s12237-014-9899-x

Haberkorn, H., Lambert, C., Le Goïc, N., Guéguen, M., Moal, J., Palacios, E., et al. (2010). Effects of Alexandrium minutum exposure upon physiological and hematological variables of diploid and triploid oysters, Crassostrea gigas. Aquat. Toxicol. 97, 96-108. doi: 10.1016/j.aquatox.2009.12.006

Hambal, H., Mohd. Akhir, A., and Saniah, Y. (1994). Environmental Issues on Aquaculture Development in Malaysia. Working papers of the Fisheries Research Institute, Department of Fisheries, Kuala Lumpur, Malaysia.

Hamdan, R., Kari, F., Othman, A., and Samsi, S. M. (2012). "Climate change, socioeconomic and production linkages in East Malaysia aquaculture sector," in 2012 International Conference on Future Environment and Energy IPCBEE, Vol. 28 (Singapore: IACSIT Press).

Hamdan, R., Othman, A., and Kari, F. (2015). Climate change effects on aquaculture production performance in Malaysia: an environmental performance analysis. Int. J. Bus. Soc. 16, 364-385. doi: 10.33736/ijbs.573.2015

Handisyde, N., Telfer, T. C., and Ross, L. G. (2017). Vulnerability of aquaculturerelated livelihoods to changing climate at the global scale. Fish Fish. 18, 466-488. doi: $10.1111 /$ faf.12186
Handisyde, N. T., Ross, L. G., Badjeck, M. C., and Allison, E. H. (2006). The Effects of Climate Change on World Aquaculture: A Global Perspective. Final Technical Report. Stirling: DFID Aquaculture and Fish Genetics Research Programme, Stirling Institute of Aquaculture.

Hardy, H. (2010). Utilization of plant proteins in fish diets: effects of global demand and supplies of fish meal. Aquac. Res. 41, 770-776. doi: 10.1111/j.1365-2109.2009.02349.x

Harvey, B., Soto, D., Carolsfeld, J., Beveridge, M., and Bartley, D. M. (Eds.). (2017). Planning for Aquaculture Diversification: The Importance of Climate Change and Other Drivers. FAO Technical Workshop, 23-25 June 2016. FAO Fisheries and Aquaculture Proceedings No. 47. Rome: FAO, 166 pp.

Hégaret, H., Brokordt, K. B., Gaymer, C. F., Lohrmann, K. B., García, C., and Varela, D. (2012). Effects of the toxic dinoflagellate Alexandrium catenella on histopathogical and escape responses of the Northern scallop Argopecten purpuratus. Harmful Algae 18, 74-83. doi: 10.1016/j.hal.2012.04.006

Hinder, S. L., Hays, G. C., Edwards, M., Roberts, E. C., Walne, A. W., and Gravenor, M. B. (2012). Changes in marine dinoflagellate and diatom abundance under climate change. Nat. Clim. Change 2, 271-275. doi: 10.1038/nclimate1388

Hoegh-Guldberg, O., Mumby, P. J., Hooten, A. J., Steneck, R. S., Greenfield, P., Gomez, E., et al. (2007). Coral reefs under rapid climate change and ocean acidification. Science 318, 1737-1742. doi: 10.1126/science.1152509

Holmyard, N. (2014). "Climate change: implications for fisheries and aquaculture," in Key Findings From the Intergovernmental Panel on Climate Change Fifth Report, ed J. Benn (Cambridge: European Climate Foundation, The Sustainable Fisheries Partnership, University of Cambridge's judge Business School and Institute for Sustainable Leadership), 1-16. Available online at: https:// www.intechopen.com/books/climate-change-and-variability/climate-changeimpacts-on-fisheries-and-aquaculture

IPCC (2013). Summary for Policymakers, The Physical Science Basis. Contribution of Working Group I to the Fifth Assessment Report of the Intergovernmental Panel on Climate Change. Cambridge; New York, NY: Cambridge University Press.

IPCC (2014). Climate change 2014: Synthesis Report. Contribution of Working Groups I, II and III to the Fifth Assessment Report on the Intergovernmental Panel on Climate Change. Core writing team, R. K. Pachauri and L.A. Meyer. Geneva: Intergovernmental Panel on Climate Change, 151 pp. Available online at: http://www.ipcc.ch/pdf/assessmentreport/ar5/syr/SYR_ AR5_FINAL_full_wcover.pdf

IPCC (2018). Global Warming of $1.5^{\circ} \mathrm{C}$. An IPCC Special Report on the Impacts of Global Warming of $1.5^{\circ} \mathrm{C}$ Above Pre-industrial Levels and Related Global Greenhouse Gas Emission Pathways, in the Context of Strengthening the Global Response to the Threat of Climate Change, Sustainable Development, and Efforts to Eradicate Poverty, eds V. Masson-Delmotte, P. Zhai, H.-O. Pörtner, D. Roberts, J. Skea, P. R. Shukla, A. Pirani, W. Moufouma-Okia, C. Péan, R. Pidcock, S. Connors, J. B. R. Matthews, Y. Chen, X. Zhou, M. I. Gomis, E. Lonnoy, T. Maycock, M. Tignor, and T. Waterfield.

IPCC (2019). Special Report on Climate Change, Desertification, Land Degradation, Sustainable Land Management, Food Security, and Greenhouse Gas Fluxes in Terrestrial Ecosystems, Summary for Policymakers Approved Draft. Geneva: IPCC.

Jahan, A., Nipa, T. T., Islam, S. M. M., Uddin, M. H., Islam, M. S., and Shahjanan, M. (2019). Striped catfish (Pangasianodon hypophthalmus) could be suitable for coastal aquaculture. J. Appl. Ichthyol. 35, 994-1003. doi: 10.1111/jai.13918

Johnston, P., Everard, M., Santillo, D., and Robert, K. H. (2007). Reclaiming the definition of sustainability. Environ. Sci. Pollut. Res. 14, 60-66. doi: 10.1065/espr2007.01.375

Kandu, P. (2017). "Papua New Guinea. Impacts of climate variations on local fisheries and aquaculture resources in PNG," in Ecological Risk Assessment of Impacts of Climate Change on Fisheries and Aquaculture Resources, ed E. J. Ramos (Peru: APEC Ocean and Fisheries Working Group). 45-49.

Kettle, N. P., Dow, K., Tuler, S., Webler, T., Whitehead, J., and Miller, K. M. (2014). Integrating scientific and local knowledge to inform risk-based management approaches for climate adaptation. Clim. Risk Manage. 17-31. doi: 10.1016/j.crm.2014. 07.001

Khaine, I., and Woo, S. Y. (2015). An overview of interrelationship between climate change and forests. For. Sci. Technol. 11, 11-18. doi: $10.1080 / 21580103.2014 .932718$ 
Khatri-Chhetri, A., Regmi, P. P., Chanana, N., and Aggarwal, P. K. (2019). Potential of climate-smart agriculture in reducing women farmers' drudgery in high climatic risk areas. Clim. Change 158, 29-42. doi: 10.1007/s10584-018-2350-8

Kibria, G., Haroon, Y. A. K., and Dayanthi, N. (2017). Climate change impacts on tropical and temperate fisheries, aquaculture, and seafood security and implications-a review. Livestock Res. Rural Dev. 29:22.

King, A. D., and Harrington, L. J. (2018). The inequality of climate change from 1.5 to $2{ }^{\circ} \mathrm{C}$ of global warming. Geophys. Res. Lett. 45, 5030-5033. doi: 10.1029/2018GL078430

Klinger, D. H., Levin, S. A., and Watson, J. R. (2017). The growth of finfish in global open-ocean aquaculture under climate change. Proc. R. Soc. B 284:20170834. doi: $10.1098 / \mathrm{rspb} .2017 .0834$

Kobayashi, M., Msangi, S., Batka, M., Vannuccini, S., Dey, M. M., and Anderson, J. L. (2015). Fish to 2030: the role and opportunity for aquaculture. Aquac. Econ. Manage. 19, 282-300. doi: 10.1080/13657305.2015.994240

Koblinsky, C. J., Hildebrand, P., LeVine, D., Pellerano, F., Chao, Y., Wilson, W., et al. (2003). Sea surface salinity from space. Sci. Goals Meas. Approach Radio Sci. 38:7. doi: 10.1029/2001RS002584

Kroeker, K. J., Gaylord, B., Hill, T. M., Hosfelt, J. D., Miller, S. H., and Sanford, E. (2014). The role of temperature in determining species' vulnerability to ocean acidification: a case study using Mytilus galloprovincialis. PLoS ONE. 9:e100353. doi: 10.1371/journal.pone.0100353

Lafferty, K. D. (2009). The ecology of climate change and infectious diseases. Ecology 90, 888-900. doi: 10.1890/08-0079.1

Laffoley, D. (2013). Introduction to the special issue: The global state of the ocean; interactions between stresses, impacts and some potential solutions. Synthesis papers from the International Programme on the State of the Ocean 2011 and 2012 workshops. Ma. Pollut. Bull. 74, 491-494. doi: 10.1016/j.marpolbul.2013.06.057

Leal Filho, W. (2011). Experiences of Climate Change Adaptation in Africa. Berlin; Heidelberg: Springer.

Lemasson, A. J., Hall-Spencer, J. M., Fletcher, S., Provstgaard-Morys, S., and Knights, A. M. (2018). Indications of future performance of native and nonnative adult oysters under acidification and warming. Mar. Environ. Res. 142, 178-189. doi: 10.1016/j.marenvres.2018.10.003

Lesperance, A. (2017). Indigenous Traditional Knowledge Remains Marginalized in Canada's Healthcare System. Canada's Healthcare System. Available online at: https://www.abs-canada.org/featured/indigenous-traditional-knowledgeremains-marginalized-in-canadas-healthcare-system

Lim-Camacho, L., Hobday, A. J., Bustamante, R. H., Farmery, A., Fleming, A., Frusher, S., et al. (2014). Facing the wave of change: stakeholder perspectives on climate adaptation for Australian seafood supply chains. Reg. Environ. Change 15, 595-606. doi: 10.1007/s10113-014-0670-4

Lorenzen, K., Ainsworth, C. H., Baker, S. M., Barbieri, L. R., Camp, E. V., Dotson, J. R., et al. (2017). "Climate Change Impacts on Florida's fisheries and aquaculture sectors and options for adaptation," in Florida's Climate: Changes, Variations, and Impacts. Retrieved from: http://purl.flvc.org/fsu/fd/ FSU_libsubv1_scholarship_submission_1515510950_127e8200

Magrin, G. O., Marengo, J. A., Boulanger, J. P., Buckeridge, M. S., Castellanos, E., Poveda, G., et al. (2014). "Central and South America," in Climate Change 2014: Impacts, Adaptation, and Vulnerability. Part B: Regional Aspects. Contribution of Working Group II to the Fifth Assessment Report of the Intergovernmental Panel on Climate Change, eds V. R. Barros, C. B. Field, D. J. Dokken, M. D. Mastrandrea, K. J. Mach, T. E. Bilir, et al. (Cambridge; New York, NY: Cambridge University Press), 1499-1566.

Makondo, C. C., and Thomas, D. S. G. (2018). Climate change adaptation: linking indigenous knowledge with western science for effective adaptation. Environ. Sci. Policy 88, 83-91. doi: 10.1016/j.envsci.2018.06.014

Malcorps, W., Kok, B., van't Land, M., Fritz, M., van Doren, D., Servin, K., et al. (2019). The sustainability conundrum of fishmeal substitution by plant ingredients in shrimp feeds. Sustainability 15:1212. doi: 10.3390/su11041212

Mangan, S., Urbina, M. A., Findlay, H. S., Wilson, R. W., and Lewis, C. (2017). Fluctuating seawater $\mathrm{pH} / \mathrm{pCO}_{2}$ regimes are more energetically expensive than static $\mathrm{pH} / \mathrm{pCO}_{2}$ levels in the mussel Mytilus edulis. Proc. R. Soc. B 284:20171642. doi: 10.1098/rspb.2017.1642

Marcogliese, D. J. (2008). The impact of climate change on the parasites and infectious diseases of aquatic animals. Rev. Sci. Tech. Off. Int. Epiz 27, 467-484. doi: $10.20506 /$ rst.27.2.1820
Marshall, N. A., Marshall, P. A., Tamelander, J., Obura, D., Malleret-King, D., and Cinner, J. E. (2009). A Framework for Social Adaptation to Climate Change: Sustaining Tropical Coastal Communities [SIC] and Industries. Avaialable online at: https://portals.iucn.org/library/efiles/documents/2010-022.pdf

Maulu, S., Munganga, B. P., Hasimuna, O. J., Haambiya, L. H., and Seemani, B. (2019). A review of the science and technology developments in Zambia's aquaculture industry. J. Aquac. Res. Dev. 10:567. doi: $10.4172 / 2155-9546.1000 .567$

Maulu, S., and Musuka, C. G. (2018). Assessing the abundance and distribution of Tilapia species in Lake Kariba. Int. J. Fish. Aquac. Sci. 8, 1-11.

Merino, G., Barange, M., Blanchard, J. L., Harle, J., Holmes, R., Allen, I., et al. (2012). Can marine fisheries and aquaculture meet fish demand from a growing human population in a changing climate? Glob. Environ. Change 22, 795-806. doi: $10.1016 /$ j.gloenvcha.2012.03.003

Metian, M. (2017). Aquaculture and Global Changes. Retrieved from: http://www. ocean-climate.org/wp-content/uploads/2017/03/aquaculture_ScientificNotes_ 07-14.pdf

Mohanty, B. P., Mohanty, S., Sahoo, J. K., and Sharma, A. P. (2010). Climate Change: Impacts on Fisheries and Aquaculture, Chapter 7, Climate Change and Variability. Zagreb; Rijeka: InTech. doi: 10.5772/9805

Moore, S., Trainer, V., Mantua, N., Parker, M., Laws, E., and Backer, L. (2008). Impacts of climate variability and future climate change on harmful algal blooms and human health. Environ. Health 7:S4. doi: 10.1186/1476-069X-7-S2-S4

Morash, A. J., and Alter, K. (2015). Effects of environmental and farm stress on abalone physiology: perspectives for abalone aquaculture in the face of global climate change. Rev. Aquac. 8, 342-368.doi: 10.1111/raq.12097

Morris, J. P., Backeljau, T., and Chapelle, G. (2019). Shells from aquaculture: a valuable biomaterial, not a nuisance waste product. Rev. Aquac. 11, 42-57. doi: 10.1111/raq.12225

Munday, P. L., Dixson, D. L., Donelson, J. M., Jones, G. P., Pratchett, M. S., Devitsina, G. V., et al. (2009). Ocean acidification impairs olfactory discrimination and homing ability of a marine fish. Proc. Natl. Acad. Sci. U.S.A. 106, 1848-1852. doi: 10.1073/pnas.0809996106

Munday, P. L., Hernaman, V., Dixson, D. L., and Thorrold, S. R. (2011). Effect of ocean acidification on otolith development in larvae of a tropical marine fish. Biogeosciences 8, 1631-1641. doi: 10.5194/bg-8-1631-2011

Myers, S. S., Smith, M. R., Guth, S. Golden, C. D., Vaitla, B., Mueller, N. D., et al. (2017). Climate change and global food systems: potential impacts on food security and undernutrition. Annu. Rev. Public Health 38, 259-77. doi: 10.1146/annurev-publhealth-031816-044356

Ngoan, L. D. (2018). Effects of climate change in aquaculture: case study in Thua Thien Hue Province, Vietnam. Biomed. J. Sci. Tech. Res. 10:2018. doi: 10.26717/BJSTR.2018.10.001892

Nguyen, L. A., Pham, T. B., Bosma, R., Verreth, J., Leemans R., De Silva, S., et al. (2018). Impact of climate change on the technical efficiency of striped catfish, Pangasianodon hypophthalmus. Farm. Mekong Delta 49, 570-581. doi: $10.1111 /$ jwas. 12488

Olesen, I., Groen, A. F., and Gjerde, B. (2000). Definition of animal breeding goals for sustainable production systems. J. Anim. Sci. 78, 570-582. doi: $10.2527 / 2000.783570 \mathrm{x}$

Osch, S. V., Hynes, S., Freeman, S., and O'Higgins, T. (2019). Estimating the public's preferences for sustainable aquaculture: a country comparison. Sustainability 11:569. doi: 10.3390/su11030569

Palmer, T., and Stevens, B. (2019). The scientific challenge of understanding and estimating climate change. Proc. Natl. Acad. Sci. U.S.A. 116, 24390-24395. doi: 10.1073/pnas.1906691116

Parker, R. W. R., Blanchard, J. L., Gardner, C., Green, B. S., Hartmann, K., Tyedmers, P. H., et al. (2018). Fuel use and greenhouse gas emissions of world fisheries. Nat. Clim. Change 8, 333-337. doi: 10.1038/s41558-018-0117-x

Paukert, C. P., Lynch, A. J., and Whitney, J. E. (2016). Effects of climate change on North American inland fishes: introduction to the special issue. Fish. Mag. 41, 329-330. doi: 10.1080/03632415.2016. 1187011

Pickering, T. D., Ponia, B., Hair, C. A., Southgate, P. C., Poloczanska, E. S., Della Patrona, L., et al. (2011). "Vulnerability of aquaculture in the tropical Pacific to climate change," in Vulnerability of Tropical Pacific Fisheries and Aquaculture to Climate Change, eds J. D. Bell, J. E. Johnson, and A. J. Hobday (Noumea: Secretariat of the Pacific Community), 647-731. 
Pongthanapanich, T., Nguyen, A. T., and Xinhua, Y. (2016). Insurance for Fishery and Aquaculture Adaptation to Climate Change Experiences From China and Vietnam. Rome: FAO.

Pörtner, H. O., Langenbuch, M., and Reipschläger, A. (2004). Biological impact of elevated ocean $\mathrm{CO}_{2}$ concentrations: lessons from animal physiology and earth history. J. Oceanogr. 60, 705-718. doi: 10.1007/s10872-004-5763-0

Preto, B. L., Henares, M. N. P., Kimpara, J. M., and Valenti, W. C. (2015). Greenhouse Gas Emissions From Aquaculture, Aquaculture Might Have Potential for Carbon Fixation. Global Aquaculture Alliance. Available online at: https://www.aquaculturealliance.org/advocate/greenhouse-emissionsfrom-aquaculture/

Richards, R. G., Davidson, A. T., Meynecke, J., Beattie, K., Hernaman, V., Lynam, T., et al. (2015). Effects and mitigations of ocean acidification on wild and aquaculture scallop and prawn fisheries in Queensland, Australia. Fish. Res. 161, 42-56. doi: 10.1016/j.fishres.2014.06.013

Riphah, S. U. (2015). Global warming: causes, effects and solutions. Durreesamin J. $1,1-7$.

Robinson, R. A., Learmonth, J. A., Hutson, A. M., Macleod, C. D., Sparks, T. H., Leech, D. I., et al. (2005). Climate Change and Migratory Species. British Trust for Ornithology. Thetford: The Nunnery.

Rodrick, G. B. (2008). Effects of temperature, salinity and pesticides on oyster hemocyte activity. Florida Water Resour. J. 4:14.

Rodrigues, L. C., Van Den Bergh, J. J. M., Massa, F., Theodorou, J. A., Ziveri, P., and Gazeau, A. F. (2015). Sensitivity of Mediterranean bivalve mollusc aquaculture to Climate change, ocean acidification, and other environmental pressures: findings from a producer survey. J. Shellfish Res. 34, 1161-1176. doi: 10.2983/035.034.0341

Rosenzweig, C., Elliott, J., Deryng, D., Ruane, A. C., Muller, C., Arneth, A., et al. (2014). Assessing agricultural risks of climate change in the 21 st century in a global gridded crop model intercomparison. Proc. Natl Acad. Sci. U.S.A. 111, 3268-73. doi: 10.1073/pnas.1222463110

Rutkayova, J., Vácha, F., Maršálek, M., Beneš, K., Civišová, H., Horká, P., et al. (2017). Fish stock losses due to extreme floods-findings from pondbased aquaculture in the Czech Republic. J. Flood Risk Manage. 11, 351-359. doi: $10.1111 /$ jfr3.12332

Saba, V. S., Griffies, S. M., Anderson, W. G., Winton, M., Alexander, M. A., Delworth, T. L., et al. (2016). Enhanced warming of the Northwest Atlantic Ocean under climate change. J. Geophys. Res. Oceans 121, 118-132. doi: 10.1002/2015JC011346

Sae-Lim, P., Kause, A., H. Mulder, A., and Olesen, I. (2017). Breeding and genetics symposium: climate change and selective breeding in aquaculture. J. Anim. Sci. 95, 1801-1812. doi: $10.2527 /$ jas2016.1066

Schjolden, A. (2004). Towards Assessing Socioeconomic Impacts of Climate Change in Norway: Sensitivity in the Primary Sectors: Fisheries, Agriculture, Agriculture and Forestry. CICERO Report 2004:03. Oslo: Center for International Climate and Environmental Research.

Seggel, A., De Young, C., and Soto, D. (2016). Climate Change Implications for Fisheries and Aquaculture: Summary of the Findings of the Intergovernmental Panel on Climate Change Fifth Assessment Report. FAO Fisheries and Aquaculture Circular No. 1122. Rome: FAO.

Shelton, C. (2014). Climate Change Adaptation in Fisheries and AquacultureCompilation of Initial Examples. FAO Fisheries and Aquaculture Circular No. 1088. Rome: FAO, 34 pp.

Silbiger, N. J., and Sorte, C. J. B. (2018). Biophysical feedbacks mediate carbonate chemistry in coastal ecosystems across spatiotemporal gradients. Sci. Rep. 8:796. doi: 10.1038/s41598-017-18736-6

Sondak, C. F. A., Ang, P. O., Beardall, J., Bellgrove, A., Boo, S. M., Gerung, G. S., et al. (2016). Carbon dioxide mitigation potential of seaweed aquaculture beds (SABs). J. Appl. Phycol. 29, 2363-2373. doi: 10.1007/s10811-016-1022-1

Stévant, P., Rebours, C., and Chapman, A. (2017). Seaweed aquaculture in Norway: recent industrial developments and future perspectives. Aquac. Int. 25, 1373-1390. doi: 10.1007/s10499-017-0120-7

Stewart, H. A., Aboagye, D. I., Ramee, S. W., and Allen, P. J. (2019). Effects of acute thermal stress on acid-base regulation, haematology, ion-osmoregulation and aerobic metabolism in Channel Catfish (Ictalurus punctatus). Aquac. Res. 50, 2133-2141. doi: 10.1111/are.14093

Sult, V. T., Aldon, M. E. T., Tendencia, I. T., Ortiz, A. M. J., Alayon, S. B., and Ledesma, A. S. (2005). Regional Technical Consultation on the
Aquaculture of P. vannamei and Other Exotic Shrimps in Southeast Asia. Manila: SEAFDEC/AQD.

Thomsen, J., Stapp, L. S., Haynert, K., Schade, H., Danelli, M., Lanning, G., et al. (2017). Naturally acidified habitat selects for ocean acidification tolerant mussels. Sci. Adv. 3:e1602411. doi: 10.1126/sciadv.1602411

Tiller, R., De Kok, J. L., Vermeiren, K., Richards, R., Ardelan, M. V., and Bailey, J. (2016). Stakeholder perceptions of links between environmental changes to their socio-ecological system and their adaptive capacity in the region of Troms, Norway. Front. Mar. Sci. 3:267. doi: 10.3389/fmars.2016.00267

Tisdell, C. A., and Leung, P. S. (1999). Overview of environmental and sustainability issues in aquaculture. Aquac. Econ. Manage. 3, 1-5. doi: 10.1080/13657309909380228

Toussaint, M., Gyalog, G., Hough, C., and Ytteborg, E. (2018). The Effects of Climate Change Upon Aquaculture. Oslo: Climefish.

Trainer, V. L., Moore, S. K., Hallegraeff, G., Kudela, R. M., Clement, A., Mardones, J. I., et al. (2019). Pelagic harmful algal blooms and climate change: lessons from nature's experiments with extremes. Harmful Algae 91:101591. doi: 10.1016/j.hal.2019.03.009

Troell, M., Eide, A., Isaksen, J., Hermansen, Ø., and Crépin, A. S. (2017). Seafood from a changing Arctic. Ambio 46, S368-S386. doi: 10.1007/s13280-017-0954-2

Troell, M., Naylor, R. L., Metian, M., Beveridge, M., Tyedmers, P. H., Folke, C., et al. (2014). Does aquaculture add resilience to the global food system? Proc. Natl. Acad. Sci. U.S.A. 111, 13257-13263. doi: 10.1073/pnas.1404067111

Valenti, W. C., Kimpara, J. M., and Preto, B. L. (2011). Measuring aquaculture sustainability. World Aquac. 42, 26-30.

Valenti, W. C., Kimpara, J. M., Preto, B. L., and Moraes-Valenti, P. (2018). Indicators of sustainability to assess aquaculture systems. Ecol. Indic. 88, 402-413. doi: 10.1016/j.ecolind.2017.12.068

VGREEN (2012). Life Cycle Assessment of Fish Feeds: Case Study in Bangladesh. WorldFish/USAID "Feed the Future-Aquaculture Bangladesh and CSISA Projects. Centre of Excellence on Environment Strategy for GREEN Business (VGREEN), Bangkok: Kasetsart University.

Wasmund, N., Nausch, G., and Matthaus, W. (1998). Phytoplankton spring blooms in the Southern North Sea, spatio-temporal development and longterm trends. J. Plankton Res. 20, 1099-1117. doi: 10.1093/plankt/20.6.1099

Weatherdon, L. V., Magnan, A. K., Rogers, A. D., Sumaila, U. R., and Cheung, W. W. L. (2016). Observed and projected impacts of climate change on marine fisheries, aquaculture, coastal tourism, and human health: an update. Front. Mar. Sci. 3:48. doi: 10.3389/fmars.2016.00048

Wittmann, A. C., and Pörtner, H. O. (2013). Sensitivities of extant animal taxa to ocean acidification. Nat. Clim. Change 3, 995-1001. doi: 10.1038/nclimate1982

Yazdi, S. K., and Shakouri, D. (2010). The effects of climate change on aquaculture. Int. J. Environ. Sci. Dev. 1, 378-382. doi: 10.7763/IJESD.2010.V1.73

Ytrestoyl, T., Aas, T. S., and Åsgård, T. (2015). Utilization of feed resources in production of Atlantic salmon (Salmo salar) in Norway. Aquaculture 448, 365-374. doi: 10.1016/j.aquaculture.2015.06.023

Zhang, P. F., Zhao, T., Zhou, L., Han, G. D., Shen, Y. W., and Ke, C. H. (2019). Thermal tolerance traits of the undulated surf clam Paphia undulata based on heart rate and physiological energetics. Aquaculture 498, 343-350. doi: 10.1016/j.aquaculture.2018.08.037

Zolnikov, T. R. (2018). "Climate change," in Autoethnographies on the Environment and Human Health, ed T. R. Zolnikov (Cham: Springer), 32-37. doi: 10.1007/978-3-319-69026-1

Zolnikov, T. R. (Ed.). (2019). Global Adaptation and Resilience to Climate Change. Palgrave Studies in Climate Resilient Societies. (Bern) doi: 10.1007/978-3-030-01213-7

Conflict of Interest: The authors declare that the research was conducted in the absence of any commercial or financial relationships that could be construed as a potential conflict of interest.

Copyright (c) 2021 Maulu, Hasimuna, Haambiya, Monde, Musuka, Makorwa, Munganga, Phiri and Nsekanabo. This is an open-access article distributed under the terms of the Creative Commons Attribution License (CC BY). The use, distribution or reproduction in other forums is permitted, provided the original author(s) and the copyright owner(s) are credited and that the original publication in this journal is cited, in accordance with accepted academic practice. No use, distribution or reproduction is permitted which does not comply with these terms. 